\title{
Ecological patterns of Chironomidae assemblages in Dynaric karst springs
}

\author{
M. Płóciennik ${ }^{1 \star}$, D. Dmitrović ${ }^{2}$, V. Pešić ${ }^{3}$ and P. Gadawski ${ }^{1}$ \\ 1 Department of Invertebrate Zoology and Hydrobiology, University of Lodz, Banacha Street 12/16, 90-237 Lodz, Poland \\ 2 Department of Biology, Faculty of Sciences, University of Banja Luka, Mladena Stojanovića 2, 78000 Banja Luka, Republic of Srpska, \\ Bosnia and Herzegovina \\ 3 Department of Biology, University of Montenegro, Cetinjski put b.b., 81000 Podgorica, Montenegro
}

Received September 1, 2015 - Revised November 23, 2015 - Accepted December 4, 2015

\begin{abstract}
Springs are one of important freshwater habitats in the Dynaric Mountains. Nevertheless, there were no intensive studies on dipteran communities in the region. Here we present an ecological analysis of Chironomidae communities recorded from a set of 27 springs along the Cvrcka River mainstream (the Republic of Srpska, Bosnia and Herzegovina). Environmental classification of Cvrcka springs divide them into three groups reflecting the level of human impact. Chironomidae communities divide investigated springs into three groups more dependent on bottom substrate quality. CCA indicates that the hard bottom and altitude are primary (significant) factors determining midge assemblages. Secondary factors influencing communities are oxygen concentration and conductivity. There are clear differences in diversity and abundance in these three types of spring communities. Type II aggregates natural sites for Cvrcka valley. Samples characterized by high abundance of Chironomus seems to be an outliers in Cvrcka canyon. Eucrenon and hypocrenon communities are distinct, but no differences in the diversity level or the environmental assemblage relation were recorded for both mesohabitats. This study proves that solely environmental classification of spring habitats reflects well human impact, but invertebrate communities may not clearly follow general classification, reacting to a set of natural and altered conditions.
\end{abstract}

Key-words: Springs / Chironomidae / crenobiology / Dynaric Mountains

Résumé - Les caractéristiques écologiques des assemblages de Chironomidae dans les sources karstiques dinariques. Les sources sont l'un des habitats d'eau douce importants dans les montagnes dinariques. Néanmoins, il n'y avait pas d'études intensives sur les communautés de diptères dans la région. Ici, nous présentons une analyse écologique des communautés de Chironomidae étudiées à partir d'un ensemble de 27 sources le long du cours principal de la rivière Cvrcka (République de Srpska, Bosnie-Herzégovine). La classification environnementale des sources Cvrcka les divise en trois groupes reflétant le niveau de l'impact humain. Les communautés de Chironomidae divisent les sources étudiées en trois groupes dépendant surtout de la qualité du substrat. La CCA indique que la dureté du substrat et l'altitude sont des facteurs primaires (significatifs) déterminants des assemblages de chironomes. Les facteurs secondaires qui influent sur les communautés sont la concentration en oxygène et la conductivité. Il existe des différences nettes dans la diversité et l'abondance de ces trois types de communautés de source. Le type II regroupe des sites naturels de la vallée Cvrcka. Les échantillons sont caractérisés par une grande abondance de Chironomus et semble être un cas atypique dans le canyon Cvrcka. Les communautés de l'eucrenon et de l'hypocrenon sont distinctes, mais aucune différence dans le niveau de diversité ou de la relation à l'environnement de l'assemblage n'a été trouvée pour ces deux mésohabitats. Cette étude prouve que la classification de l'environnement des habitats de source reflète bien l'impact humain, mais les communautés d'invertébrés peuvent ne pas bien suivre ce classement général, en réaction à un ensemble de conditions naturelles et altérées.

Mots-clés : Source / Chironomidae / crénobiologie / montagne dinarique

\section{Introduction}

Springs are ecotones between groundwater and surface waters (Webb et al., 1998) as well as between aquatic and

^ Corresponding author: mplociennik10@outlook.com terrestrial biocenoses (Cantonati et al., 2006). They reveal stable abiotic conditions in contrast to the rhithral and potamal zone (Van der Kamp, 1995). Chironomidae larvae are members of spring zoobenthos in both types of sites, eucrenal (or spring source) and hypocrenal (or springbrook) ones. 


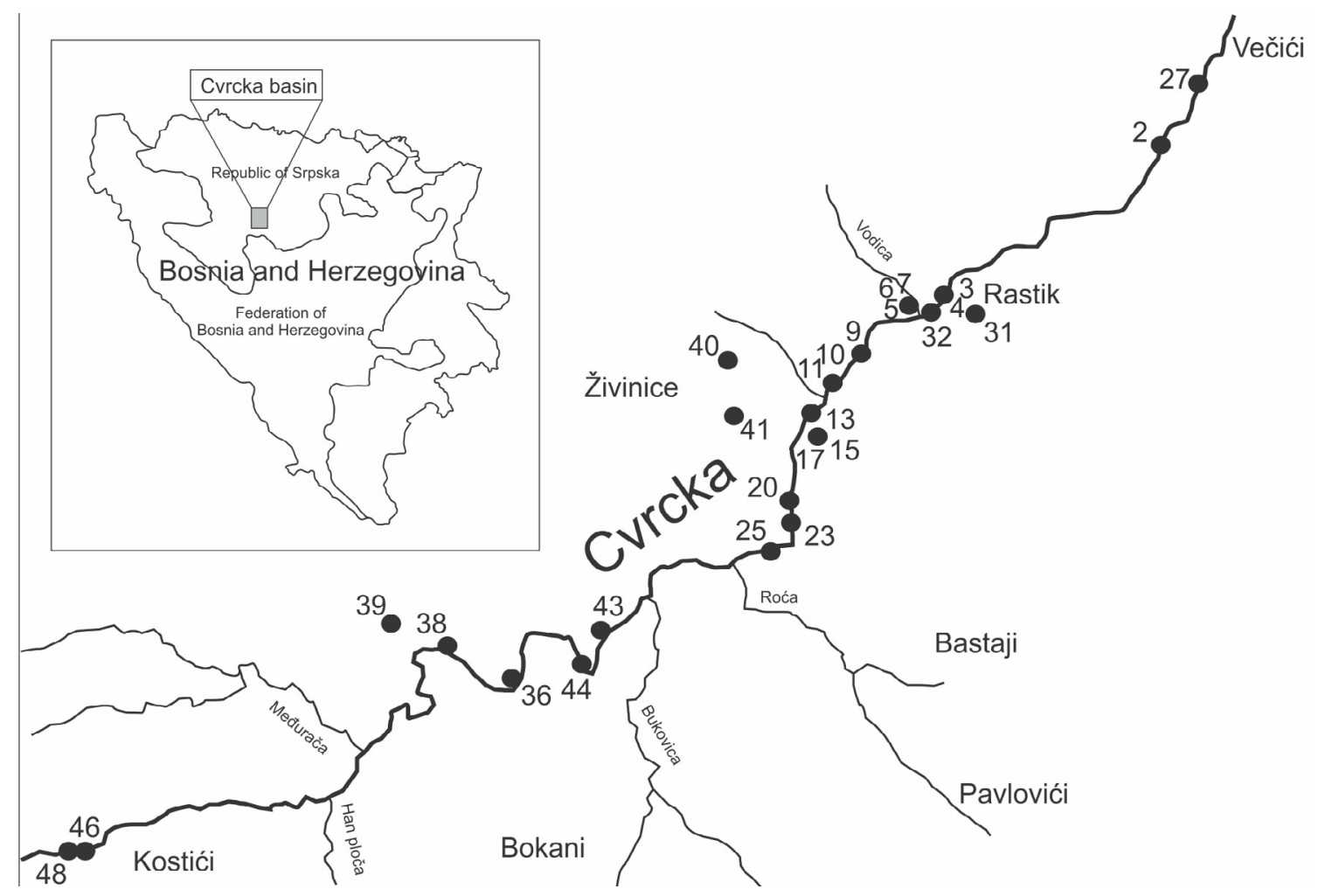

Fig. 1. Map of the study area.

In comparison to other groups of insects, Chironomidae are poorly studied in springs due to the difficulty of their larvae determination. However, it is known that ecological patterns of Chironomidae assemblages in springs can be influenced by various environmental factors (Lencioni et al., 2011; Mori and Brancelj, 2006) with an emphasis on anthropogenic activities (Ferrington, 1998), for example, by capturing springs (Lencioni et al., 2012). Although Chironomidae larvae are important community members of spring zoobenthos in Balkan Peninsula (Mori and Brancelj, 2006) and other European regions (Wagner et al., 1998), ecological patterns of their assemblages in springs of Dinaric karst are insufficiently known. This study focused on Chironomidae larvae assemblage of springs of Dinaric karst along the Cvrcka River mainstream (the NW Republic of Srpska, Bosnia and Herzegovina), where some of the investigated springs remain natural while the water quality and habitats of the others are substantially changed by human impact. Chironomidae larvae of Cvrcka River springs were not previously investigated, apart from Vilenjska Vrela spring (Filipović et al., 2009). Nevertheless, they determined collected chironomid larvae only to the family level, providing information on their density at the bottom unit area. Those data were an integral part of the research of spring macrozoobenthos community. The same approach is applied while investigating the other springs of the catchment area of the Vrbanja River, which left tributary is the Cvrcka River, (e.g. Pavlović et al., 2011) as well as the springs of the wider area of the Republic of Srpska (Pavlović et al., 2009, 2012; Mršić et al., 2009; Savić et al., 2011).

This study is conducted in the framework of a broader project focused on benthic fauna in Cvrcka River springs. One part of the springs is located in the canyon of the Cvrcka River. It is known that canyons as well as springs are refuges of many relicts and endemic species. That is why in the last years there have appeared several papers focused on the invertebrate fauna of Cvrcka River springs with the description of new probably steno-endemic species Hirudinea (Grosser et al., 2014), Gastropoda (Glöer and Pešić, 2014) and Trichoptera (Vitecek et al., 2015). All this further actualizes the importance of the research.

The aim of this study is: (1) to analyze the diversity and the distributional patterns of Chironomidae taxa in the springs along the Cvrcka River mainstream (the NW Republic of Srpska, Bosnia and Herzegovina), (2) to recognize the main environmental factors that influence Chironomidae assemblages in springs of Dinaric karst, (3) to verify how environmental classification of the springs is followed by chironomid communities themselves.

\section{Materials and methods}

\subsection{Study area}

The mainstream of the Cvrcka River (the NW Republic of Srpska, Bosnia and Herzegovina) is $14745 \mathrm{~km}$ long with its source (785 $\mathrm{m}$ a.s.1.) in Kostići village and the water mouth (315 m a.s.1.) in the Vrbanja River, downstream of Večići village (Figure 1). The climate of the Vrbanja River basin is temperate with high annual precipitation (the first maximum of precipitation is in spring and the second in autumn). Winter is the driest period of the year. The bedrock of the Cvrcka River 
basin consists mainly of limestone and the river flows predominantly through a karst canyon. There are numerous karstic springs in the river valley and its near vicinity (Rajčević and Crnogorac, 2011).

The study included springs along $12 \mathrm{~km}$ of the Cvrcka River mainstream valley. This valley section is covered mostly by deciduous forest. Rheocrenes, rheopsammocrenes and captured springs were investigated (Appendix 1).

\subsection{Field Sampling}

Chironomidae larvae were collected from 27 springs of the Cvrcka River basin. Main spring sets (PSS) representing broad springs series typical for the Cvrcka River basin, aggregates 26 springs (Appendices 2 and 4). It was used to recognize general pattern of assemblages, and macrohabitats quality. Springs S 3, S 6 from PSS set and additionally site S 31 were sampled seasonally in spring, summer and autumn. They formed together EHSS spring set (Appendices 3 and 5) and were analyzed separately to find ecological distinctness between eucrenon and hypocrenon microhabitats. Chironomids from PSS were collected during September and October 2012 and 2013 (Appendix 2). From EHSS near Rastik village chironomids were taken seasonally during the year, specific for the source (eucrenal) and water flow directly downstream (hypocrenal) (Appendix 3). Samples were collected with a hand net (350 $\mu \mathrm{m}$ mesh apertures) from all the microhabitats of the investigated springs. All the collected chironomids were preserved in $96 \%$ ethanol.

\subsection{Environmental variables}

Water temperature and $\mathrm{pH}$ values were measured with pH-meter HI 98127 accuracy 0.1, air temperature with thermometer accuracy $0.5{ }^{\circ} \mathrm{C}$, conductivity with conductometer Nahita accuracy $2 \mathrm{cF}$ and oxygen concentration with oximeter HI 9142 accuracy $0.1 \mathrm{mg} \cdot \mathrm{L}^{-1}$. Spring positions were recorded with GPS Oregon 550. Water discharge was determined by eye and grouped in classes: $1\left(<1 \mathrm{~L} \cdot \mathrm{min}^{-1}\right), 2(>1$ and $\left.<5 \mathrm{~L} \cdot \mathrm{min}^{-1}\right), 3\left(>5\right.$ and $<20 \mathrm{~L} \cdot \mathrm{min}^{-1}$ ) according to Fumetti et al. (2006). Substrate types were categorized in five classes of frequency: 0 (absent), 1 (little), 2 (medium), 3 (much), 4 (throughout) according to Hahn (2000).

\subsection{Material identification}

The material was determined mostly with Moller Pillot and Klink (2003) and Brooks et al. (2007). Ecological interpretation of taxa occurrence and their environmental preferences follow Moller Pillot (2009a, 2009b, 2013), Vallenduuk and Moller Pillot (2007), Wiederholm (1983), Moller Pillot and Klink (2003) and Brooks et al. (2007).

\subsection{Statistical analyses}

Multivariate statistics were performed for ecological interpretation of the data. Centered and standardized environmental data from the PSS were classified by Euclidean Distance similarity index and illustrated by complete linkage dendrogram (Figure 2A). For classification of biota samples, BrayCurtis similarity index on the square root transformed data was used, its results are illustrated by group average dendrogram (Figure 2B). PCA for PSS was undertaken on centered and standardized environmental data to recognize habitat diversification of the site groups used in the previous cluster analysis. Its results are presented on Figure 3, at first with marked by different colors groups of sites distinguished with environmental classification (Figure 3A, compare with Figure 2A) and secondly with sites marked after biota assemblages classification (Figure 3B, compare with Figure 2B). This is only picturing treatment, both plots (Figures 3A and 3B) illustrate the same mathematically PCA. SIMPER analysis was performed to test differences within faunal composition of the above mentioned groups A, B and C, and I, II and III (Table 3). Detrended Correspondence Analysis (DCA) was done to recognize variability gradient. As there were more than 7.1 SD units on the first two DC axes, Canonical Correspondence Analysis (CCA) was performed to find an environmental relation in taxa distribution among the samples (Figure 4, Appendix 6). Rare species were downweighted with method available in CANOCO 4.5 software. Biotic data for CCA were previously log transformed. Branches and algae were excluded from the analysis due to autocorrelation.

Because of low abundances (see Appendix 8) eukrenonhyopocrenon biotic data were not transformed. Because CCA didn't gave satisfactory results for EHSS data, Non-Metric MultiDimensional Scaling (NMDS) was performed on BrayCurtis similarity index with 25 restarts, to find a general biota compositional pattern among the samples (Figure 5). Similarity Percentage (SIMPER) analysis was done to test differences between eucrenon and hypocrenon fauna (Table 4). Principal Component Analysis (PCA) was performed on centered and standardized environmental data to find diversification of the eucrenon and hypocrenon sampling sites (not illustrated).

Shannon diversity index was calculated on both EHSS and PSS data sets. Statistical differences for diversity index between the groups were analyzed by the t-test for the EHSS data set and the ANOVA for the PSS data set.

Canoco 4.5 statistical software was used for computing DCA and CCA, C2 software for centering and standardizing environmental data (except for CCA computed by Canoco) and PRIMER 6 for all the other multivariate analysis.

\section{Results}

\subsection{Environmental features in the springs}

Water temperature of the PSS (S 2-S 48) ranged between 7.9 and $17.1{ }^{\circ} \mathrm{C}$ (mode: $13.9^{\circ} \mathrm{C}$ ) with coefficient of variation $19.20 \%$ and air temperature near the spring ranged between 15.0 and $27.0{ }^{\circ} \mathrm{C}$ (mode: $17.0{ }^{\circ} \mathrm{C}$ ) with coefficient of variation $18.36 \%$. All the springs which belong to the PSS had alkaline $\mathrm{pH}$ value which varies around a mean of $7.83 \pm 0.22$ from 7.3 to 8.2 with coefficient of variation $2.82 \%$. Conductivity of the PSS ranged between 3 and $5 \mathrm{cF}$ (mean \pm SD: $3.85 \pm$ $0.67 \mathrm{cF}$ ) with coefficient of variation $17.55 \%$ and oxygen 


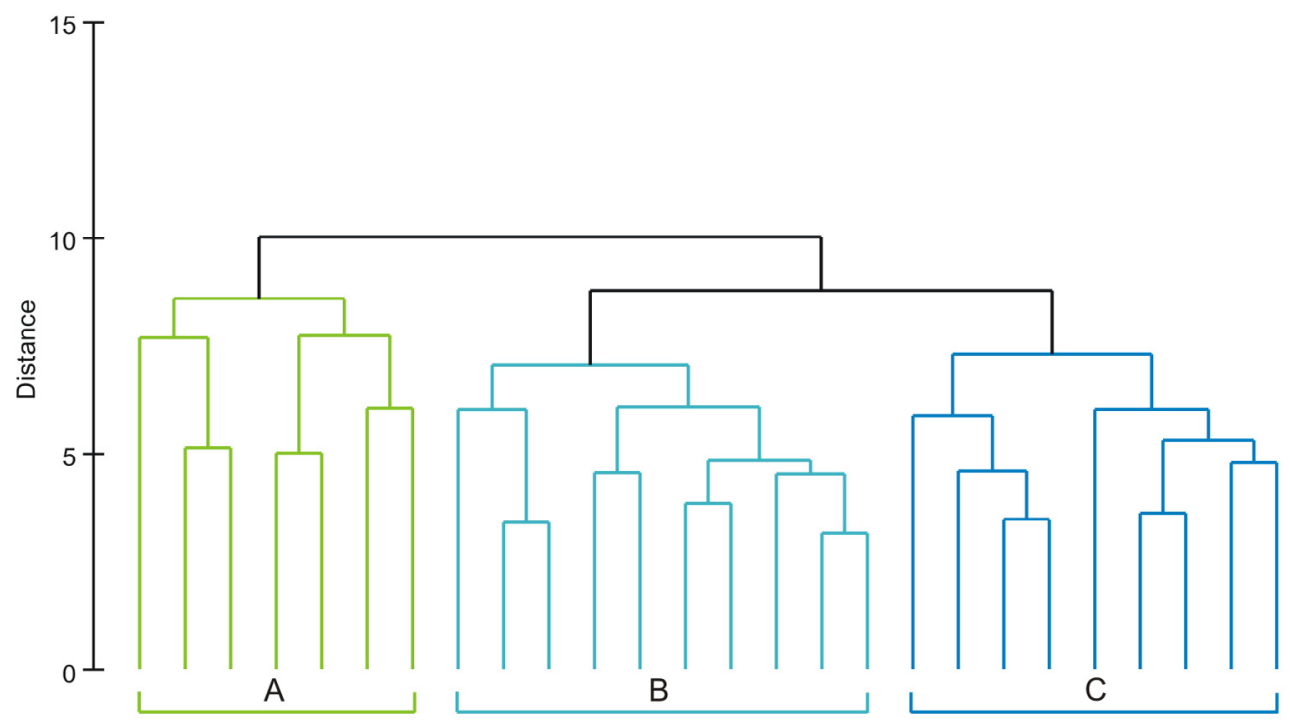

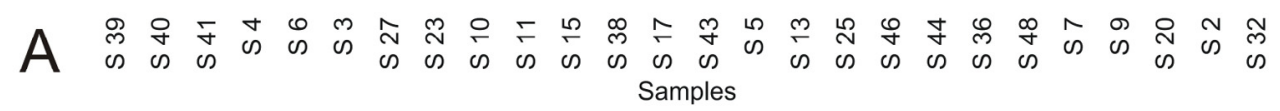

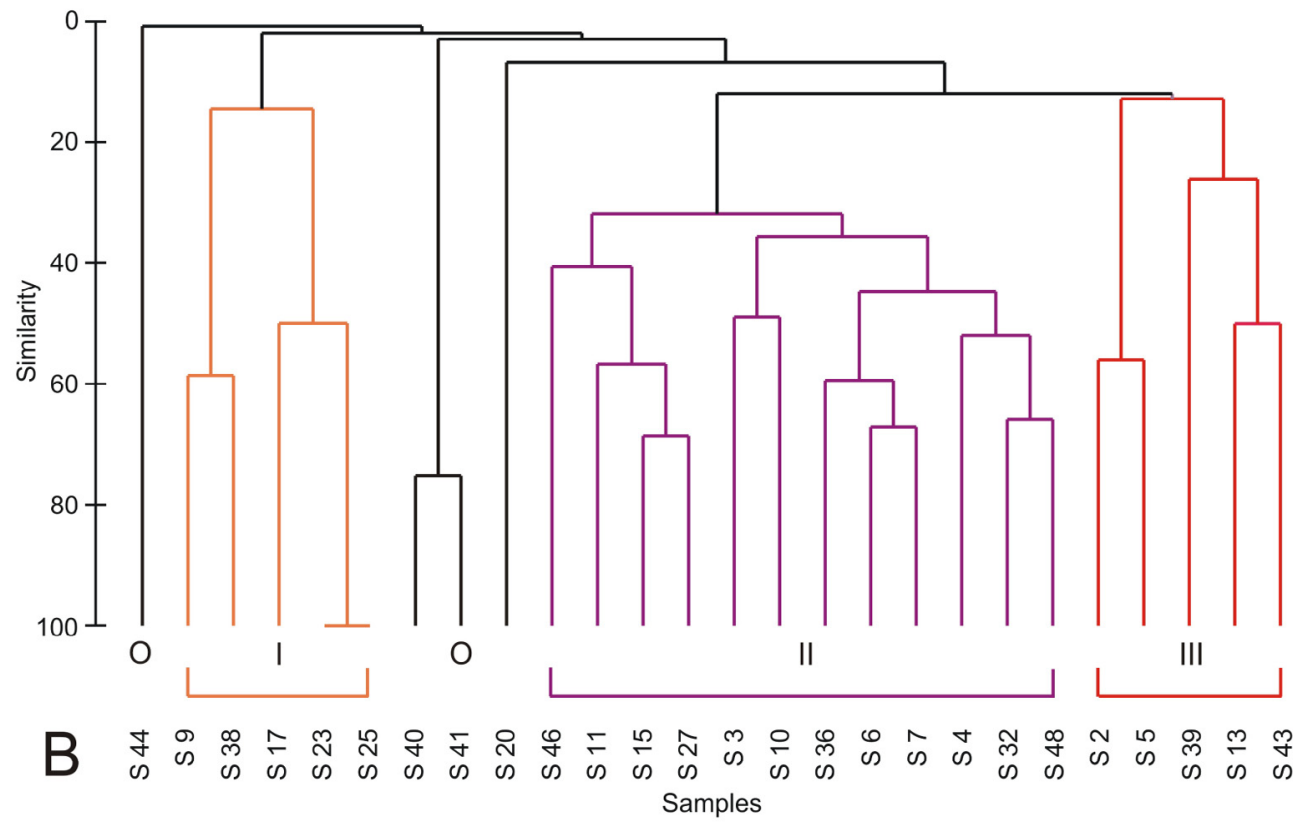

Fig. 2. (A) Similarity distance between sites in groups A, B and C reflecting environmental characteristics of the PSS. (B) Bray-Curtis similarity of Chironomidae assemblages within the PSS.

concentration varied around a mean of $6.75 \pm 1.11 \mathrm{mg} \cdot \mathrm{L}^{-1}$ from 4.0 to $8.5 \mathrm{mg} \cdot \mathrm{L}^{-1}$ with coefficient of variation $16.41 \%$.

Descriptive statistics of physical and chemical characteristics of the EHSS were analyzed by spring parts (Table 1).

Discharge at both site sets (PSS and EHSS) ranged from $<1 \mathrm{~L} \cdot \mathrm{min}^{-1}$ to $>5$ and $<20 \mathrm{~L} \cdot \mathrm{min}^{-1}$. Substrate composition of the PSS consisted of: anoxic mud, detritus, leaf litter, dead branches, moss, roots, macrophytes, clay, sand, gravel, stones, lime sinter, calcareous sinter, algae and waste materials (Appendix 4). Except algae and waste materials, all the substrate components were present in the EHSS, too (Appendix 5).

\subsection{Assemblage composition}

473 specimens from 23 taxa were collected from the PSS (S 2-S 48) in September and October 2012 and 2013 (Table 2). They represented four chironomid subfamilies (Tanypodinae, Prodiamesinae, Orthocladiinae and Chironominae). Subfamily Orthocladiinae accounted for 52\% (12 taxa) of the total, followed by Chironominae (seven taxa or 30\%), Tanypodinae (three taxa or 13\%) and Prodiamesinae (one taxon or 4\%).

All the collected chironomids were larvae. From one to seven taxa were found per spring. Only two springs (S 40 

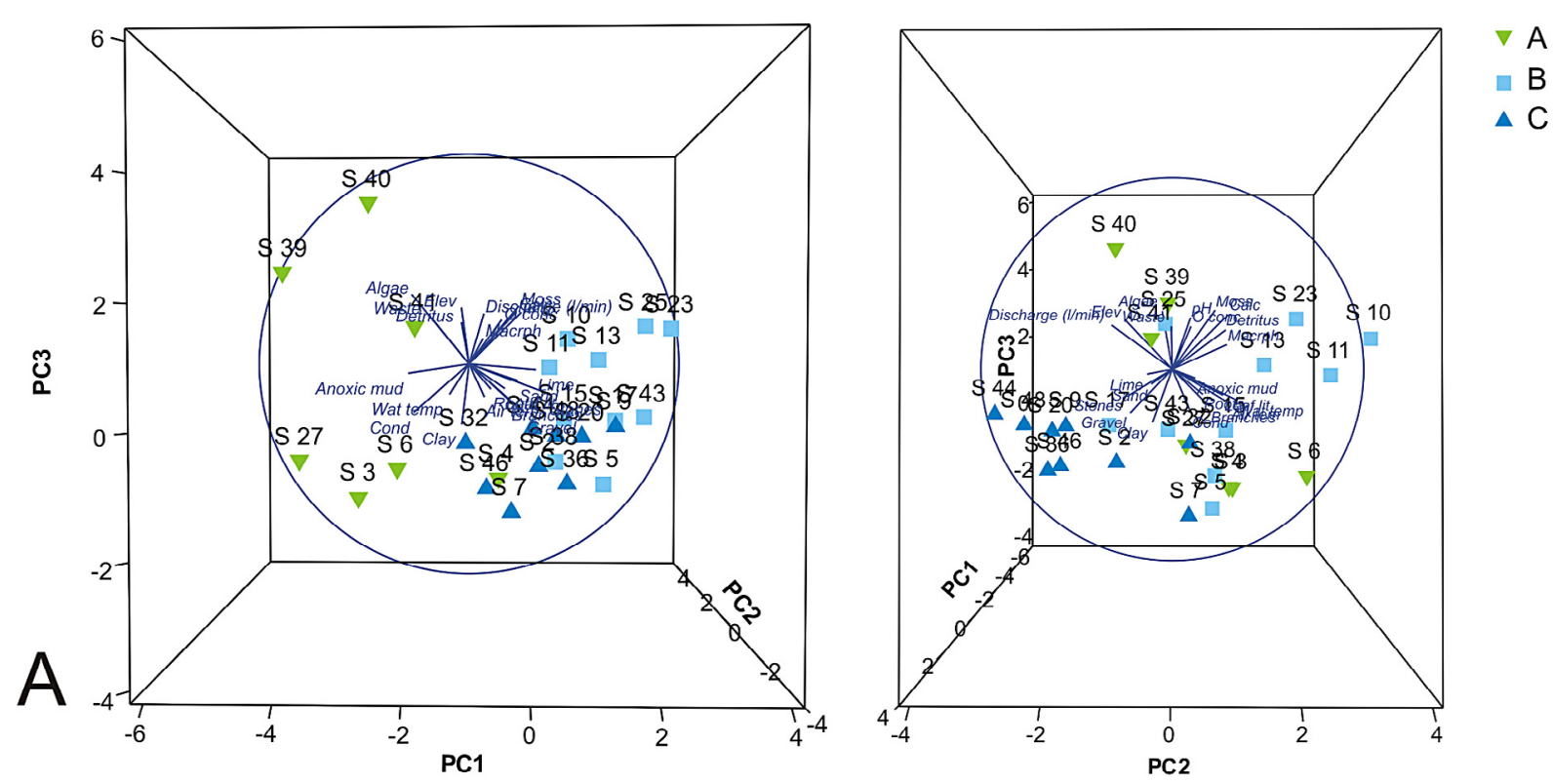

$\nabla A$

B

$\triangle \mathrm{C}$
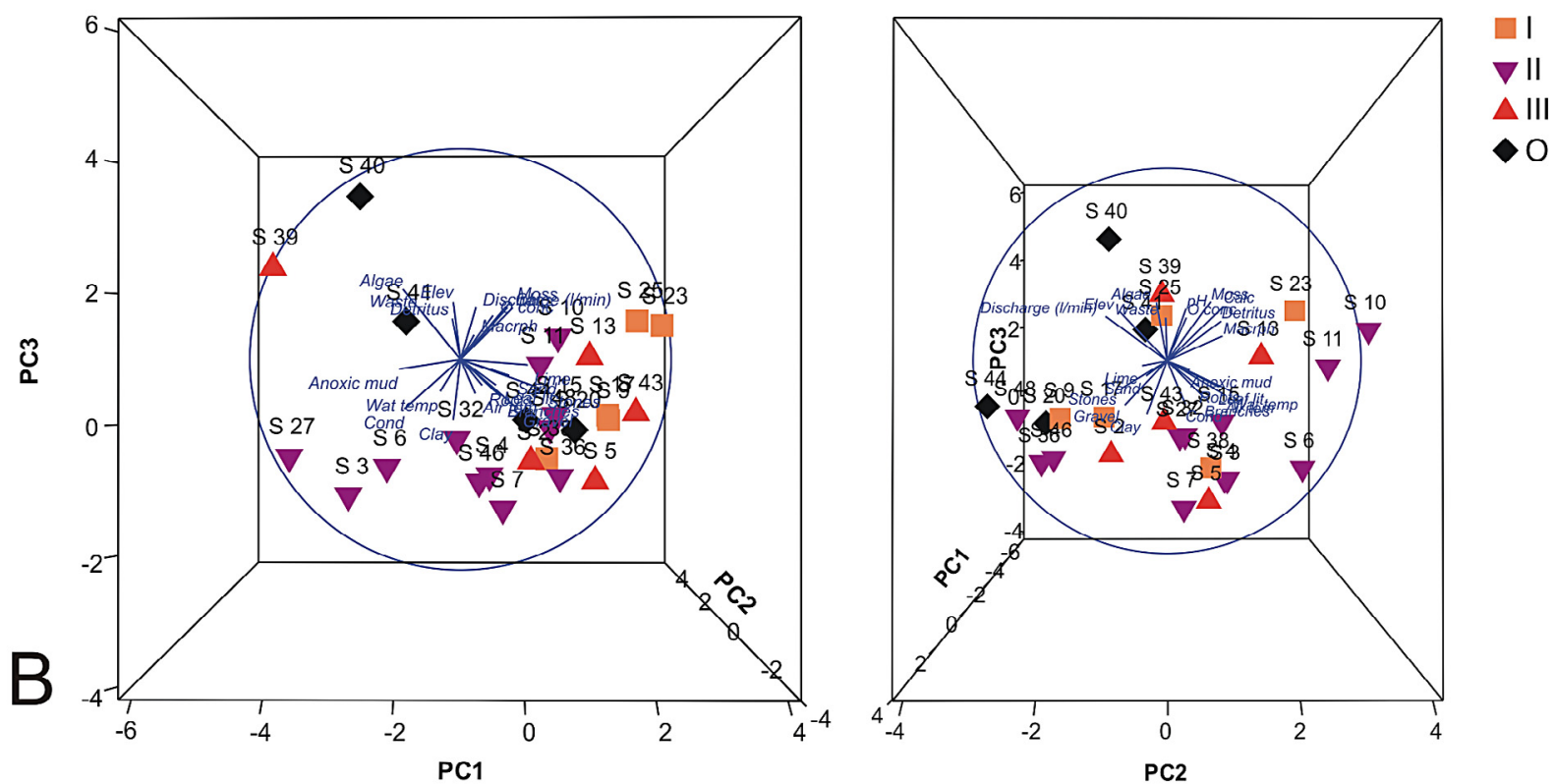

Fig. 3. (A) Results of PCA showing environmental characteristics of the PSS under classification into abiotic defined groups A, B, C. (B) Results of PCA showing environmental characteristics of the PSS under biotic classification into groups I, II, III, O (outliers).

and S 41) hosted more than 50 individuals. The most frequent taxon was Micropsectra type A (87 specimens present in 12 springs or $46 \%$ of the total 26 springs with chironomids) and the most abundant taxon was Chironomus (252 individuals).

140 specimens from 15 taxa, including larvae and singular pupal exuviae, were collected from springs S 3, S 6 and $S$ 31 (EHSS) (Table 2). Chironomidae were collected from 16 or app. $67 \%$ of the total 24 samples (Appendix 3). From one to five taxa were found per sample. Only one sample (e3103) hosted more than 20 individuals. The most frequent and the most abundant taxon was Prodiamesa olivacea (present in eight or $50 \%$ of the total 16 samples with chironomids) with 36 collected individuals.

\subsection{Community patterns}

Altogether 26 springs from the PSS may be divided into three groups (A, B and C) according to environmental conditions (Figure $2 \mathrm{~A})$.

To recognize environmental patterns in PSS, PCA was performed. The first, second and third PC axes explain respectively $21.8 \%, 17.3 \%$ and $10.6 \%$ variation of environmental variables. Results of PCA on the PSS (Figure 3A) show that 


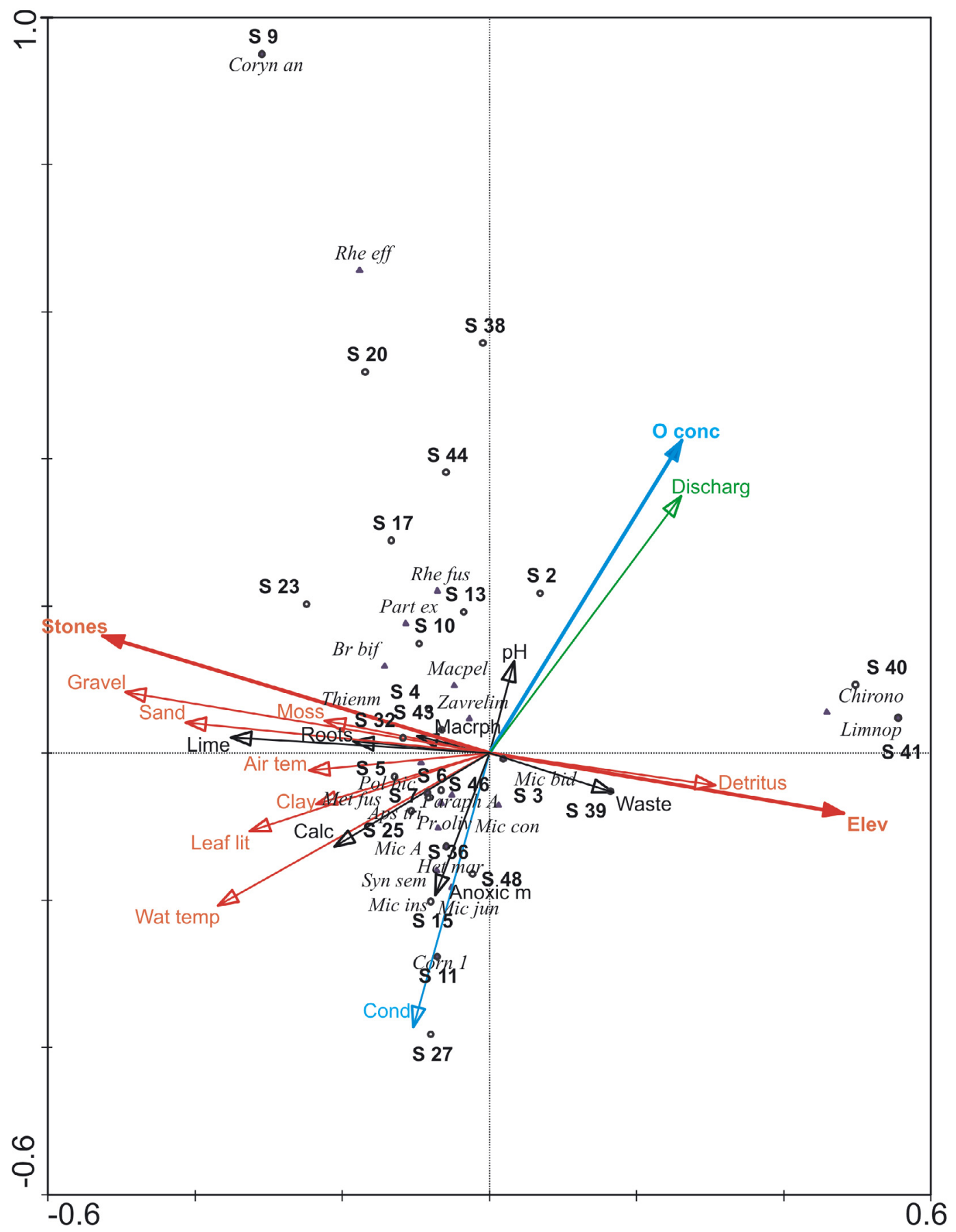

Fig. 4. Results of CCA for the PSS.

the sites in group A reveal a strong gradient in waste and algae amount. These sites are characterized by intermediate values and near 0 variation in temperature, discharge, macrophyte occurrence and calcium content, as well as by high content of anoxic mud and low concentration of lime stones. The sites from group B are distinct in high macrophyte abundance and calcium content. These sites reveal higher water temperature but lower discharge than groups $\mathrm{A}$ and $\mathrm{C}$, intermediate to low algae and waste amount, the highest lime stone concentration and the lowest amount of anoxic mud. The sites from group C manifest a relatively small variation of sediment composition (lime stones to anoxic mud), high discharge, macrophyte and calcium concentration and low temperature. Table 3 presents taxa mostly associated for each of site groups and dissimilarity in taxonomic composition between each of the groups. Micropsectra type A is characteristic for groups A and C. Chironomus is characteristic for the sites from group A, Prodiamesa olivacea show higher contribution to group C, whereas Paraphaeonocladius type A and Brillia bifida are characteristic for group B. 
Table 1. Physical and chemical characteristics of the EHSS.

\begin{tabular}{|l|c|c|c|c|c|}
\cline { 2 - 6 } \multicolumn{1}{c|}{} & $\begin{array}{c}\text { Spring } \\
\text { part }\end{array}$ & $\begin{array}{c}\text { Water } \\
\text { temperature } \\
\left({ }^{\circ} \mathrm{C}\right)\end{array}$ & $\begin{array}{c}\text { pH } \\
\text { value }\end{array}$ & $\begin{array}{c}\text { Conductivity } \\
(\mathrm{cF})\end{array}$ & $\begin{array}{c}\text { Oxygen } \\
\text { concentration } \\
\left(\mathrm{mg}^{-1}\right)\end{array}$ \\
\hline \multirow{2}{*}{ Minimum } & eucrenal & 8.2 & 7.3 & 3 & 4.0 \\
& hypocrenal & 8.7 & 7.4 & 3 & 5.9 \\
\hline \multirow{2}{*}{ Maximum } & eucrenal & 15.2 & 8.0 & 6 & 7.5 \\
& hypocrenal & 15.2 & 8.0 & 5 & 7.8 \\
\hline \multirow{2}{*}{ St. Dev. } & eucrenal & 11.98 & 7.65 & 4.08 & 6.77 \\
\hline Coef. & hypocrenal & 12.01 & 7.72 & 3.83 & 7.11 \\
Var. $(\%)$ & eucrenal & 2.24 & 0.2 & 0.9 & 0.97 \\
& hypocrenal & 2.23 & 0.17 & 0.72 & 0.58 \\
\hline
\end{tabular}

Stress: 0,01

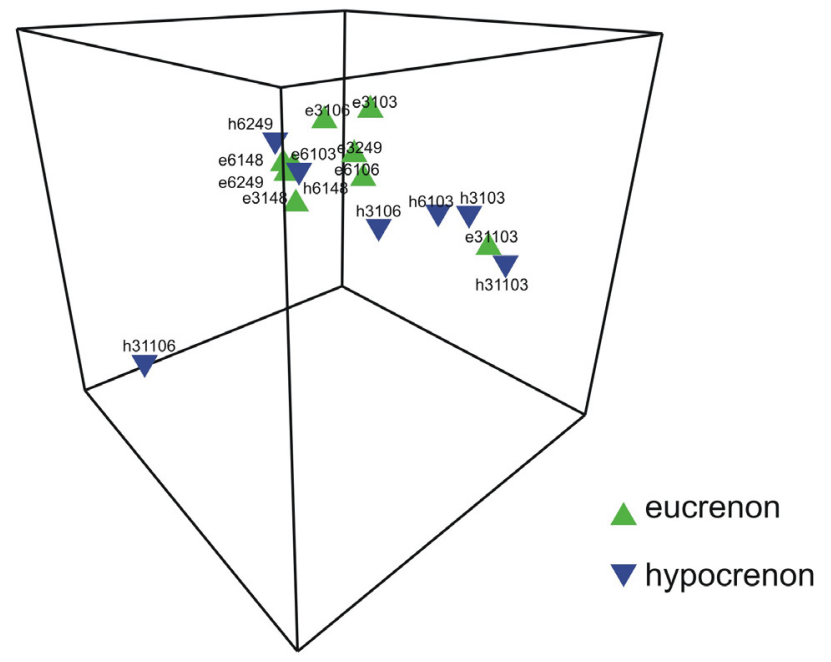

Fig. 5. Results of the NMDS analysis showing a general gradient in chironomid assemblages in the eucrenon-hypocrenon spring zone.

The chironomid assemblages from the PSS may be divided into three groups (Figure 2B).

Most of the springs aggregates in group II, two smaller supplementary groups are I and III. Outliers encompasses 4 sites (S 44, S 40, S 41 and S 20) which do not belong to any cluster. PCA (Figure 3B) shows environmental conditions that favor such defined communities recorded at the study sites. Assemblages of the springs in group I form on the lime stone bottom, species belonging to communities I avoid anoxic mud. Algae and waste do not seem to correlate to occurrence of this group, while temperature, discharge, amount of calcium and macrophyte presence reveal a strong gradient within the sites of group I. The communities from group II are present on diverse bottom from anoxic mud to lime stones habitats. They reveal a strong variation along discharge, temperature, macrophyte amount and calcium content values. The species from this group clearly avoid waste and algae. The species from group III occur generally on the lime stone bottom, without anoxic mud content and do not seem to have a clear preference in terms of discharge, temperature, waste, algae and macorphye appearance. The outlier assemblages reveal a stronger correlation with algae and waste appearance. The species from this group prefer higher discharge, lower temperature and avoid habitats with macrophytes but reveal a strong variation according to anoxic mud and lime stone content.

Table 3 clearly indicates that the community groups specified in the biotic site classification (I, II, III) are much better defined, have higher internal similarity and are more dissimilar to each other than assemblages of A, B and C groups separated it on the habitat site classification. Brillia bifida and Rheocricotopus effusus are characteristic representatives of assemblages type I., while Micropsectra type A and Prodiamesa olivacea are distinct for assemblages type II. Paraphaenocladius type A and Zavrelimyia are typical of springs from group III and Chironomus separates outliers from the others.

ANOVA found significant difference $(P=0.0001)$ for the Shannon diversity index between PSS assemblages of site groups I, II and III. Highest diversity reveal assemblage type II (mean: $1.19, \mathrm{SD}: \pm 0.35$ ), lowest assemblage type I (mean: 0.35, SD: \pm 0.45 ), intermediate values keeps type III (mean: $0.53, \mathrm{SD}: \pm 0.30)$.

Results of CCA (Figure 4, Appendix 6) summarize main trends of chironomid-environmental relation. The first two axes explain $32.5 \%$ of species-environment relation. Two environmental factors significantly influence chironomid communities: stones (explaining $6.98 \%$ of variation with $P=0.012$ ) and elevation (explaining $7.34 \%$ of variation with $P=0.014$ ). The factor which has almost a similar significance in terms of influence on chironomid communities is oxygen concentration (explaining $5.19 \%$ of variation with $P=0.11$ ). Ten factors are associated with Axis 1: elevation and detritus positively, while stones, moss, gravel, sand, air temperature, clay, leaf litter and water temperature negatively. Two factors are associated with Axis 2: oxygen concentration positively and conductivity negatively. Discharge is associated with Axis 1 and Axis 2 positively. Although most of the environmental factors, including significant ones, are associated with Axis 1, they differentiate only assemblages of springs from 40 and 41 from outliers and taxa Chironomus and Limnophyes from all the other assemblages and species. Chironomus and Limnophyes tend to occur on higher elevated sites more enriched by detritus. According 
Table 2. List of Chironomidae taxa collected in all the investigated spring sites.

\begin{tabular}{|c|c|c|c|c|}
\hline Subfamily & Taxa & Taxacode & PSS & EHSS \\
\hline Tanypodinae & $\begin{array}{c}\text { Apsectrotanypus trifascipennis } \\
\text { Macropelopia } \\
\text { Zavrelimyia }\end{array}$ & $\begin{array}{c}\text { Aps tri } \\
\text { Macpel } \\
\text { Zavrelim }\end{array}$ & $\begin{array}{l}+ \\
+ \\
+\end{array}$ & $\begin{array}{l}+ \\
+ \\
+\end{array}$ \\
\hline Prodiamesinae & Prodiamesa olivacea & Proliv & + & + \\
\hline Orthocladiinae & $\begin{array}{c}\text { Brillia bifida } \\
\text { Corynoneura sp. } 1 \\
\text { Corynoneura } \text { cf. antennalis } \\
\text { Heterotrissocladius marcidus - type } \\
\text { Limnophyes } \\
\text { Metriocnemus fuscipes - type } \\
\text { Parametriocnemus stylatus - type } \\
\text { Paraphaenocladius sp. A } \\
\text { Paratrissocladius excerptus } \\
\text { Paratrissocladius } \\
\text { Rheocricotopus effusus }- \text { type } \\
\text { Rheocricotopus fuscipes }- \text { type } \\
\text { Synorthocladius semivirens } \\
\text { Thienemannia }\end{array}$ & $\begin{array}{l}\text { Brbif } \\
\text { Corn } 1 \\
\text { Coryn an } \\
\text { Het mar } \\
\text { Limnop } \\
\text { Metfus } \\
\text { Prm sty } \\
\text { ParaphA } \\
\text { Part ex } \\
\text { Partriss } \\
\text { Rheeff } \\
\text { Rhefus } \\
\text { Synsem } \\
\text { Thienm }\end{array}$ & $\begin{array}{l}+ \\
+ \\
+ \\
+ \\
+ \\
+ \\
+ \\
+ \\
+ \\
+ \\
+ \\
+ \\
+\end{array}$ & $\begin{array}{l}+ \\
+ \\
+ \\
+\end{array}$ \\
\hline Chironominae & $\begin{array}{c}\text { Chironomus } \\
\text { Polypedilum bicrenotum - type } \\
\text { Micropsectra type A } \\
\text { Micropsectra bidentata - type } \\
\text { Micropsectra contracta - type } \\
\text { Micropsectra insignilobus - type } \\
\text { Micropsectra junci - type } \\
\text { Tanytarsus nemorosus - type }\end{array}$ & $\begin{array}{l}\text { Chirono } \\
\text { Pol bic } \\
\text { Mic A } \\
\text { Mic bid } \\
\text { Mic con } \\
\text { Mic ins } \\
\text { Micjun } \\
\text { Tan nem }\end{array}$ & $\begin{array}{l}+ \\
+ \\
+ \\
+ \\
+ \\
+ \\
+\end{array}$ & $\begin{array}{l}+ \\
+ \\
+ \\
+ \\
+ \\
+\end{array}$ \\
\hline
\end{tabular}

to CCA, all the other taxa are more associated with lower elevated sites with the mineral bottom, including coarse fractions such as stones, leaf litter and moss. These taxa are found in higher temperatures. A much stronger variation is revealed by taxa and assemblages according to the gradient in oxygen concentration and conductivity. Axis 2 divides assemblages from group I, which is associated with higher oxygen concentration and lower conductivity, from assemblages II, which are more related to higher conductivity and appear in lower oxygen concentration. Groups III and outliers reveal intermediate oxygen and conductivity conditions.

\subsection{Eucrenon-hypocrenon distinctness}

The analyzed environmental EHSS data do not provide clear separation of the eucrenon and hypocrenon zone. PCA indicates that eucrenon sites (not illustrated) reveal slightly higher values of temperature and macrophyte amount, while hypocrenon stretches have higher oxygen concentration, branches and sand on the bottom but this pattern is very weak and insignificant. According to community composition, they have clearly distinct assemblages (Figure 5). Hypocrenon communities manifest a strong gradient in assemblage composition from near similar to eucrenon to very distinct from one, whereas eucrenon assemblages are more concentrated.
Prodiamesa olivacea and Paraphaenocladius type A separate eucrenon from hypocrenon zone communities (Table 4) but Micropsectra type A inhabits both types of mesohabitats. Both zones do not differ clearly in biodiversity and species richness. Eucrenon assemblages seem to reveal higher larvae abundance, whereas hypocrenon communities reveal slightly higher evenness.

A $t$-test found no significant difference in mean values for Shannon diversity index between eucrenon and hypocrenon $(P=0.250)$.

\section{Discussion}

Chironomidae larvae are an important component of mountain spring communities in the Balkan Region (Mori and Brancelj, 2006) and other European countries (Wagner et al., 1998). As many as $20 \%$ of all chironomid species appear in spring habitats in the Holarctic region (Ferrington, 1998). In 27 springs of Cvrcka valley, there were 23 taxa recorded, whereas in the Italian Alps the number of species ranges from 81 taxa collected from 124 springs (Lencioni et al., 2012) to as many as 104 species/groups in 81 springs (Lencioni et al., 2011). Although it is difficult to distinguish truly crenobiotic species, many chironomid taxa are recognized to be crenophilous (Marziali et al., 2010; Lencioni 
Table 3. A) Results of SIMPER analysis for PSS assemblages of site groups A, B and C. B) Results of SIMPER analysis for PSS assemblages of site groups I, II, III and O (outliers).

\begin{tabular}{|c|c|c|c|c|c|c|c|c|c|c|c|}
\hline \multicolumn{3}{|c|}{$\begin{array}{l}\text { Group A } \\
\text { Average similarity: } 20.00\end{array}$} & \multicolumn{3}{|c|}{$\begin{array}{l}\text { Groups C\&A } \\
\text { Average dissimilarity }=\mathbf{8 5 . 4 2}\end{array}$} & \multicolumn{3}{|c|}{$\begin{array}{l}\text { Group I } \\
\text { Average similarity: } 34.55\end{array}$} & \multicolumn{3}{|c|}{$\begin{array}{l}\text { Groups II \& I } \\
\text { Average dissimilarity }=98.23\end{array}$} \\
\hline \multicolumn{3}{|c|}{$\begin{array}{l}\text { Group B } \\
\text { Average similarity: } 15.51\end{array}$} & \multicolumn{3}{|c|}{$\begin{array}{l}\text { Groups C\&B } \\
\text { Average dissimilarity }=89.36\end{array}$} & \multicolumn{3}{|c|}{$\begin{array}{l}\text { Group II } \\
\text { Average similarity: } 38.74\end{array}$} & \multicolumn{3}{|c|}{$\begin{array}{l}\text { Groups III \& I } \\
\text { Average dissimilarity }=97.24\end{array}$} \\
\hline \multicolumn{3}{|c|}{$\begin{array}{l}\text { Group C } \\
\text { Average similarity: } 14.23\end{array}$} & \multicolumn{3}{|c|}{$\begin{array}{l}\text { Groups A\&B } \\
\text { Average dissimilarity }=\mathbf{8 7 . 9 2}\end{array}$} & \multicolumn{3}{|c|}{$\begin{array}{l}\text { Group III } \\
\text { Average similarity: } 23.49\end{array}$} & \multicolumn{3}{|c|}{$\begin{array}{l}\text { Groups III \& II } \\
\text { Average dissimilarity }=88.09\end{array}$} \\
\hline Species & Av.Abund & Av.Sim & $\operatorname{Sim} / \mathrm{SD}$ & Contrib\% & Cum.\% & \multirow{2}{*}{\multicolumn{3}{|c|}{$\begin{array}{l}\text { Outliers } \\
\text { Average similarity: } \mathbf{1 2 . 5 2}\end{array}$}} & \multirow{2}{*}{\multicolumn{3}{|c|}{$\begin{array}{l}\text { Outliers \& I; \& II; \& III } \\
\text { Average dissimilarity = 99.41; } \\
=96.25 ;=97.12\end{array}$}} \\
\hline $\begin{array}{l}\text { A } \\
\text { Mic A }\end{array}$ & 1.42 & 7.63 & 0.60 & 38.17 & 38.17 & & & & & & \\
\hline Chirono & 3.48 & 6.96 & 0.41 & 34.81 & 72.99 & Species & Av.Abund & Av.Sim & $\operatorname{Sim} / \mathrm{SD}$ & Contrib\% & Cum.\% \\
\hline Proliv & 0.71 & 2.08 & 0.39 & 10.38 & 83.37 & I & & & & & \\
\hline Paraph A & 0.29 & 1.25 & 0.22 & 6.27 & 89.64 & Br bif & 0.60 & 20.00 & 0.57 & 57.88 & 57.88 \\
\hline $\begin{array}{l}\text { Mic con } \\
\text { B }\end{array}$ & 0.49 & 0.77 & 0.22 & 3.86 & 93.50 & $\begin{array}{l}\text { Rheeff } \\
\text { II }\end{array}$ & 0.68 & 14.55 & 0.61 & 42.12 & 100.00 \\
\hline Paraph A & 0.71 & 5.73 & 0.49 & 36.98 & 36.98 & Mic A & 2.43 & 24.04 & 2.90 & 62.06 & 62.06 \\
\hline Br bif & 0.30 & 4.44 & 0.25 & 28.66 & 65.64 & Proliv & 1.14 & 7.84 & 0.76 & 20.23 & 82.29 \\
\hline Mic A & 0.74 & 1.80 & 0.26 & 11.58 & 77.22 & Paraph A & 0.43 & 1.54 & 0.30 & 3.98 & 86.27 \\
\hline Zavrelim & 0.44 & 1.58 & 0.26 & 10.16 & 87.38 & Part ex & 0.40 & 1.35 & 0.30 & 3.47 & 89.74 \\
\hline $\begin{array}{l}\text { Rheeff } \\
\text { C }\end{array}$ & 0.20 & 1.11 & 0.15 & 7.17 & 94.55 & $\begin{array}{l}\text { Mic ins } \\
\text { III }\end{array}$ & 0.37 & 1.03 & 0.31 & 2.65 & 92.40 \\
\hline Mic A & 1.31 & 4.91 & 0.57 & 34.52 & 34.52 & Paraph A & 1.13 & 17.89 & 1.04 & 76.14 & 76.14 \\
\hline Proliv & 0.86 & 4.10 & 0.42 & 28.83 & 63.35 & Zavrelim & 0.84 & 5.60 & 0.32 & 23.86 & 100.00 \\
\hline Part ex & 0.46 & 2.08 & 0.26 & 14.60 & 77.96 & Outliers & & & & & \\
\hline Zavrelim & 0.70 & 2.05 & 0.29 & 14.41 & 92.37 & Chirono & 5.49 & 12.52 & 0.41 & 100.00 & 100.00 \\
\hline
\end{tabular}

et al., 2011). Therefore, they have a higher potential for spring bioassessment and conservation than other insects. Nevertheless, Lencioni et al. (2011) and Lencioni et al. (2012) report only few taxa to achieve high abundance and frequency within their site sets. As in the Dinaric Mountains, in the Alps and other Holarctic localities, Orthocladiinae are the species richest group (Ferrington, 1998; Marziali et al., 2010), whereas in Cvrcka River valley the presence of Diamesinae was not recorded. This may indicate some degradation of springs in this valley compared to the Alpine highlands (Lencioni et al., 2011). The midge fauna of mountain springs is relatively diverse. Species richness tends to increase from the uplands to mountain elevations 1250-2250 m a.s.l., due to higher habitat heterogeneity (Lencioni et al., 2011, Lencioni et al., 2012).

The research in Cvrcka River valley prove that environmental and biotic classification of springs may not match. Environmental classification provides three clear groups of sites which indicate human impact on the habitat, landscape transformation and spring typology. Springs which belong to group $\mathrm{A}$ are under a strong human influence, particularly springs S 39, S 40 and S 41, which are captured springs in the central part of villages and their water is extensively used for drinking and watering livestock. Spring S 27 and S 6 are also captured, but they are located outside villages. Rheocrene springs S 3 and S 4 are located on the forest edge near Rastik village. All the other springs avoided a direct human impact. Most of the springs from group B are located in a valley with a deciduous forest. Some of the springs are captured, but they are not in use. Most of the springs from group $C$ are upstream
Table 4. Results of SIMPER analysis for EHSS assemblages.

\begin{tabular}{|c|c|c|c|c|}
\hline \multicolumn{4}{|c|}{$\begin{array}{l}\text { Group e } \\
\text { Average similarity: } 17.30\end{array}$} & \\
\hline \multicolumn{4}{|c|}{$\begin{array}{l}\text { Group h } \\
\text { Average similarity: } 8.76\end{array}$} & \\
\hline \multicolumn{4}{|c|}{$\begin{array}{l}\text { Groups e } \& \text { h } \\
\text { Average dissimilarity }=87.20\end{array}$} & \\
\hline Species & Av.Sim & $\overline{S i m} / \mathrm{SD}$ & Contrib\% & Cum.\% \\
\hline \multicolumn{4}{|l|}{ e } & \\
\hline Pro liv & 8.70 & 0.65 & 50.31 & 50.31 \\
\hline Mic A & 4.99 & 0.38 & 28.84 & 79.15 \\
\hline Mic con & 1.59 & 0.39 & 9.18 & 88.33 \\
\hline $\begin{array}{l}\text { Aps tri } \\
\text { h }\end{array}$ & 1.27 & 0.24 & 7.37 & 95.70 \\
\hline Paraph A & 4.80 & 0.37 & 54.81 & 54.81 \\
\hline Mic A & 1.73 & 0.22 & 19.77 & 74.58 \\
\hline Rhe eff & 1.36 & 0.22 & 15.54 & 90.11 \\
\hline
\end{tabular}

(S 46 and S 48) or downstream (S 2, S 7, S 9 and S 32) in relation to Cvrcka River canyon. They are more easily accessible to people compared to the springs from group B, but their water is not used intensively, due to the fact that most of them are located in the forest. Lencioni et al. $(2011,2012)$ and Ivković et al. (2015) prove human impact on terrestrial spring surroundings and canopy cover has a strong influence 
on midge communities. Nevertheless, chironomid communities in Cvrcka valley divide sites into three groups and this biotic classification does not match the one based solely on environmental characteristics. Midge communities are also much more dissimilar than springs according to their environmental character. High faunistic dissimilarity between springs, even located nearby, is indicated by Lencioni et al. (2011). PCA indicates that midge communities in the Dinaric Mountains are strongly correlated to the bottom character, whereas such conditions as temperature and discharge are variable within assemblage types. Algae and waste are an important factor that influences species composition. Peryphyton is an important food supply for many midge species. Waste is often an artificial substrate for algae, especially if the natural bottom is composed of fine sediments. Algal vegetation is also enhanced by supply of nutrients, therefore eutrophicated, garbled springs should have specific chironomid fauna. It is symptomatic that communities type II, which reveal highest diversity, do not exist in garbled springs with ample algae vegetation. Assemblage II with Micropsectra and Prodiamesa olivacea seems to be natural, typical for the Cvrcka River basin, as it comprises the highest number of sites. Prodiamesa olivacea is also the most common species in springs in the Volga basin (Chuzhekova, 2014). It is likely that communities type I with Brillia bifida and Rheocricotopus effusus as well as III with Paraphaenocladius and Zavrelimyia inhabit two accessory natural spring types, and their occurrence depends on oxygen saturation and bottom type. Outliers reveal strong Chironomus domination. They are rheocrenes of cold, fast flowing water on higher elevation. They seem to be less typical for Cvrcka valley and associated with more garbled sites with ample algae vegetation. Springs S 40 and S 41 are situated in a village. These are huge captured springs with a high flow rate. Spring S 20 is located in the forest but in proximity of a settled area. Spring 44 is located in a small cave. This habitat diversity can be the reason why its assemblages do not aggregate with any other. CCA clearly separates sites of higher Chironomus and Limnophyes domination as being higher elevated, with more detritus on the bottom. A similar pattern was found in the Evortas River basin (Southern Greece). The mountain spring assemblages revealed higher Chironomus domination. Limnophyes and Chironomus tend to co-occur in the Evortas springs in more degraded sites (Karaouzas and Płóciennik, 2016). Ferrington (1998) indicates that springs influenced by human impact, frequented by cattle, are inhabited be taxa typical to lower-order enriched streams and have higher domination of Chironomini, namely Chironomus species. Lencioni et al. (2012) indicate Limnophes to be also associated with captured springs. This species prefers the hygropetric zone in limnocrenes and appears on the rocky bottom with bryophytes (Lencioni et al., 2011). Barquín and Death (2004) suggest that moss mats may accumulate detritus and provide good habitat for algae development. This may explain higher dominance of the above mentioned taxa in some of the springs, disturbed and natural as well. All the other species recorded in Cvrcka valley are associated with lower elevation and the stony bottom with a more mineral fraction. It is symptomatic that only stones and elevation shaped assemblages to a statistically significant degree. Factors such as presence of hard bottom, temperature, current and stream per- manence associated with these two significant factors might have an indirect influence on the communities. Elevation and temperature are factors influencing chironomid communities on the broad, geographical scale (Ferrington, 1998). Mori and Brancelj (2006), Marziali et al. (2010) and Lencioni et al. (2011, 2012) indicate altitude, peryphiton, sediment quality, temperature and flow character to be the main drivers of biotic diversity in springs. In the Italian Alps, there is a strong positive correlation of habitat quality and chironomid diversity with altitude. Lencioni et al. (2012) find bed modification to cause diversity decrease whereas moderate eutrophication to favor species richness. In fact, all the other communities and species in Cvrcka River springs are more spread along the second CCA axis. Oxygen concentration and conductivity may play an important role while they remain insignificant according to the Monte Carlo Permutation test. We suppose they may be underestimated in this case. Communities II aggregating sites typical of Cvrcka valley occur in higher conductivity and lower oxygen concentration, whereas types I and III appear usually in better oxygen conditions and lower conductivity. Assemblages variability along the second CCA axis may in fact reflect water chemical composition. We have only information on $\mathrm{pH}$, oxygen concentration and conductivity but other compounds such as nutrients and/or e.g.: sulfides, not measured, may have an influence on chironomids. In the Italian Alps (Marziali et al., 2010, Lencioni et al., 2011, 2012) pH, conductivity and water trophy are primary conditions differing highland pristine springs from upland disturbed ones. This pattern is not so relevant in boreal springs where mean annual temperature changing through climatic zones in a longitudinal gradient plays the main role. Ferrington (1998), Staudacher and Füreder (2007) draw attention to microhabitat complexity as the main driver of aquatic insect species composition, biodiversity and abundance. In the Eastern Alps, microhabitat heterogeneity and moister of the spring zones from fully aquatic, semiaquatic, to terrestrial - is linked to insect diversity. Chironomidae were spread through all those zones. In Eastern Alpine springs, chemical factors (such as conductivity) and altitude have only a weak influence on invertebrate communities (Staudacher and Füreder, 2007). Species composition and community structure manifest variability not only between spring types spread along Cvrcka valley but also in microhabitats within springs. In this study, no differences in diversity or species richness were observed between euand hypocrenon. Mc Cabe (1998) reviews a number of examples from North America and Europe where a decrease or an increase of species richness with distance from the source was observed, so there is no general pattern, whereas individual gradients in species distribution were commonly observed. Rheocrene springs are proved to contain diverse niches and are species rich in chironomids (Lencioni et al., 2012) and other insects (Cianficconi et al., 1998). It is difficult to separate clearly defined types of springs, a gradual transition from one spring type to another is what can be observed instead (Lencioni et al., 2011). NMDS and SIMPER analyses show that eucrenon and hypocrenon have different community composition in Cvrcka valley. Eucrenon assemblages are more specific due to higher uniformity of such habitats. Hypocrenon assemblages reveal a gradient ranging from more 
similar to more distinct from eucrenon. This is visible in the characteristic species groups for these two kinds of mesohabitats. In other studies Prodiamesa olivacea species was found in helocrenes and rheo-limnocrenes, Micropsectra species was recorded in the hygropetric zone with mineral sediment and bryophytes, Paraphaenocladius is usually found in brooks and telmatic margins of spring on the soft bottom, whereas Apsectrotanypus trifascipennis and Rheocricotopus effusus are typical for soft sediments in small flowing waters and helocrenes (Moller Pillot, 2013; Vallenduuk and Moller Pillot, 2007; Lencioni et al., 2011). Clear differences in assemblage composition indicated by NMDS and SIMPER are not confirmed by PCA which does not confirm environmental differences between these two kinds of habitats.

\section{Conclusions}

The investigated springs defy simple classification. Communities reflect well environmental parameters measured, but the environmental parameters alone do not give information how the community uses them. Whereas habitat structure, namely bottom composition, discharge and temperature, may explain to some extend community diversification, in this case only elevation and hard-bottom availability were significantly important factors. It seems that other, chemical factors, such as oxygen concentration, nutrients or diverse compounds responsible for conductivity that influence groundwater quality, may also play an important role for chironomids in springs in the Dynaric Mountains, but only investigation of a larger area and more detailed environmental data may prove that. Ecology of Balkan Peninsula springs remains relatively poorly recognized compared to temperate Europe, Apennine and Iberian Peninsulas. Unique climatic and geological conditions indicate a significant need for broader research of spring fauna of the region, especially due to the role which it plays in karstic landscape. Chironomidae are a key group of habitat quality indicators especially on the species level. Taxa, which here were recognized to be 'characteristic' for certain habitat quality, comprise high number of species (e.g. Chironomus, Limnophyes, diverse Micropsectra morphotypes) and are only ecological units. They leave only restricted space for exact interpretation or an ecological relation of environment and community. Further studies in the region should pay more attention to a wide database (including also a robust number of individuals) and high taxonomical resolution.

Acknowledgements. We would like to thank Slaven Filipović, Goran Šukalo and Siniša Škondrić for help in the field works to Rafal Szperna and Paulina Wyszkowska for Laboratory works and professional translator Marta Koniarek for linguistic correction.

\section{References}

Barquín J. and Death R.G., 2004. Patterns of invertebrate diversity in streams and freshwater springs in Northern Spain. Arch. Hydrobiol., 161, 329-349.

Brooks S.J., Langdon P.G. and Heiri O., 2007. The Identification and use of Palaearctic Chironomidae Larvae in Palaeoecology,
QRA Technical Guide No. 10, Quaternary Research Association, London, 276 p.

Cantonati M., Gerecke R. and Bertuzzi E., 2006. Springs of the Alps, sensitive ecosystems to environmental change: from biodiversity assessments to long-term studies. In: Lami A. and Boggero A. (eds.), Ecology of high altitude aquatic systems in the Alps. Developments of Hydrobiology. Hydrobiologia, 562, 59-96.

Chuzhekova T.A., 2014. Spatio-temporal structure of macroinverterbrate community in springs and springbrooks of middle Volga basin. Kaamos Symposium 8-9.12.2014, Oulu. Abstracts of talks.

Cianficconi F., Carallini C. and Moretti. G.P., 1998. Trichopteran fauna of Itailian springs. In: Botosaneanu L. (ed.), Studies in Crenobiology, The biology if springs and springbrooks. Backhuys Publishers, Leiden, 125-140.

Ferrington L.C. Jr., 1998. Generic composition of Chironomid fauna in springs of North America. In: Botosaneanu L. (ed.), Studies in Crenobiology, The biology if springs and springbrooks. Backhuys Publishers, Leiden, 141-155.

Filipović S., Pavlović N., Pavlović B.P. and Savanović D., 2009. Stanje taksocena zoobentosa krenona u slivu Vrbanje: 1. Vilenska vrela. In: Ilić P. (ed.), Zbornik radova. Naučno-stručni skup sa međunarodnim učešćem "Zaštita i zdravlje na radu i zaštita životne sredine", Institut zaštite, ekologije i informatike, Naučnoistraživački institut, Banja Luka, 323-329.

Fumetti S., Nagel P., Scheifhacken, N. and Baltes B., 2006. Factors governing macrozoobenthic assemblage in perennial springs in north-western Switzerland. Hydrobiologia, 568, 467-475.

Glöer P. and Pešić V., 2014. Belgrandiella bozidarcurcici n. sp., a new species from Bosnia and Herzegovina (Gastropoda: Hydrobiidae). Arch. Biol. Sci., 66, 461-464.

Grosser C., Pešić V. and Dmitrović D., 2014. Dina sketi n. sp., a new erpobdellid leech (Hirudinida: Erpobdellidae) from Bosnia and Herzegovina. Zootaxa, 3793, 393-397.

Hahn H.J., 2000. Studies on classifyng of undisturbed spring in Southwestern Germany by macrobenthic communities. Limnologica, 30, 247-259.

Ivković M., Miliša M., Baranov V. and Mihaljević Z., 2015. Environmental drivers of biotic traits and phenology patterns of Diptera assemblages in karst springs: The role of canopy uncovered. Limnologica 54, 44-57.

Karaouzas I. and Płóciennik M. 2016, Spatial scale effects on Chironomidae diversity and distribution in a Mediterranean River Basin. Hydrobiologia, 767, 81-93.

Lencioni V., Marziali L. and Rossaro B., 2011. Diversity and distribution of chironomids (Diptera, Chironomidae) in pristine Alpine and pre-Alpine springs (Northern Italy). J. Limnol., 70, 106-121.

Lencioni V., Marziali L and Rossaro B., 2012. Chironomids as bioindicators of environmental quality in mountain springs. Freshw. Sci., 31, 525-541.

Marziali L., Lencioni V. and Rossaro B., 2010. The chironomids (Diptera: Chironomidae) from 108 Italian Alpine springs. Verh. Int. Ver. Theor. Angew. Limnol., 30, 1467-1470.

Mc Cabe D.J., 1998. Biological communites in springbrooks. In: Botosaneanu L. (ed.), Studies in Crenobiology, The biology if springs and springbrooks, Backhuys Publishers, Leiden, 221-228

Moller Pillot H.K.M., 2009a. A key to the larvae of the aquatic Chironomidae of the North-West European Lowlands, private print, not published, $77 \mathrm{p}$.

Moller Pillot H.K.M., 2009b. Chironomidae Larvae, Biology and Ecology of the Chironomini, KNNV Publishing, Zeist, $270 \mathrm{p}$.

Moller Pillot H.K.M., 2013. Chironomidae Larvae, Volume 3: Biology and Ecology of the Aquatic Orthocladiinae, KNNV Publishing, Zeist, 312 p. 
Moller Pillot H.K.M. and Klink A.G., 2003. Chironomidae larvae. Key to higher taxa and species of the lowlands of Northwestern Europe. - CD-ROM, ETI, Amsterdam.

Mori N. and Brancelj A., 2006. Macroinvertebrate communities in karst springs of two river catchments in the Southern Limestone Alps (the Julian Alps, NW Slovenia). Aquatic Ecol., 40, 69-83.

Mršić M., Maksimović T., Pajčin R and Filipović S., 2009. Stanje taksocena zoobentosa krenona u slivu Strižne i Vojskove. In: Ilić P. (ed.), Zbornik radova. Naučno-stručni skup sa međunarodnim učešćem "Zaštita i zdravlje na radu i zaštita životne sredine", Institut zaštite, ekologije i informatike, Naučnoistraživački institut, Banja Luka, 331-338.

Pavlović N., Pavlović P.B., Pajčin R., Filipović S., Dmitrović D. and Mršić M., 2009. Stanje taksocena zoobentosa krenona u slivu Sutjeske. In: Ilić P. (ed.), Naučno-stručni skup sa međunarodnim učešćem "Zaštita i zdravlje na radu i zaštita životne sredine", Institut zaštite, ekologije i informatike, Naučnoistraživački institut, Banja Luka, 427-440.

Pavlović N., Pavlović B.P., Dmitrović D., Pajčin R. and Filipović S., 2011. Zoobentos izvora gornjeg dijela sliva Vrbanje. Skup, $4,13-23$.

Pavlović N., Balta M. and Dmitrović D., 2012. Longitudinalni raspored zoobentosa rječice Krupe pritoke Vrbasa. In: Redžić S. (ed.), Zbornik radova. Međunarodni naučni skup "Struktura i dinamika ekosistema Dinarida - stanje, mogućnosti i perspektive", Akademija nauka i umjetnosti Bosne i Hercegovine, Sarajevo, 57-72.

Rajčević V. and Crnogorac B.Č., 2011. Rijeka Vrbanja - Fiziogena svojstva sliva i riječnog sistema. "ARTPRINT", Banja Luka, $276 \mathrm{p}$.
Savić K., Pavlović N. and Dmitrović D., 2011. Stanje taksocena zoobentosa izvora slivnog područja Sane na Kozari. Skup, 3, 3-12.

Staudacher K. and Füreder L., 2007. Habitat Complexity and Invertebrates in Selected Alpine Springs (Schütt, Carinthia, Austria). Int. Rev. Hydrobiol., 92, 465-479.

Vallenduuk H.J. and Moller Pillot H.K.M., 2007. Chironomidae Larvae of the Netherlands and Adjacent Lowlands. General Ecology and Tanypodinae, KNNV Publishing, Zeist, 143 p.

Van der Kamp R.O., 1995. The hydrogeology of springs in relation to the biodiversity of spring fauna: a review. In: Ferrington L.C. Jr. (ed.), Biodiversity of aquatic insects and other invertebrates in springs. J. Kans. Entomol. Soc., 68, 4-17.

Vitecek S., Previšić A., Kučinić M., Bálint M., Keresztes L., Waringer J., Pauls S.U., Malicky H. and Graf W., 2015. Description of a new species of Wormaldia from Sardinia and a new Drusus species from the Western Balkans (Trichoptera, Philopotamidae, Limnephilidae). Zookeys, 496, 85-103.

Wagner R., Fischer J. and Schnabel S., 1998. The Dipteran commuinity of Central Europaean springs: a summary. In: Botosaneanu L. (ed.), Studies in Crenobiology, The biology if springs and springbrooks, Backhuys Publishers, Leiden, 157-165.

Webb D.W., Wetzel M.J., Reed P.C., Philippe L.R and Young T.C., 1998. The macroninvertebrate biodiversity, water quality, and hydrogeology of ten karst springs in the Salem Plateau of Illinois. In: Botosaneanu L. (ed.), Studies in crenobiology: the biology of springs and springbrooks, Backhuys Publishers, Leiden, 39-48.

Wiederholm T., 1983. Chironomidae of the Holarctic region. Keys and diagnoses. Part 1. Larvae. Entomol. Scand. Suppl., 19, 457.

Cite this article as: M. Płóciennik, D. Dmitrović, V. Pešić and P. Gadawski, 2016. Ecological patterns of Chironomidae assemblages in Dynaric karst springs. Knowl. Manag. Aquat. Ecosyst., 417, 11. 
Appendix 1: General characteristics of springs sampled along the Cvrcka River mainstream. The spring code follows general spring classification according to benthological studies in the Cvrcka River.

\begin{tabular}{|c|c|c|c|c|c|}
\hline $\begin{array}{l}\text { Spring } \\
\text { code }\end{array}$ & Longitude & Latitude & $\begin{array}{l}\text { Elevation } \\
\text { (m) }\end{array}$ & Spring type & Land use \\
\hline S 2 & $44^{\circ} 33.944^{\prime} \mathrm{N}$ & $17^{\circ} 25.493^{\prime} \mathrm{E}$ & 351 & rheocrene & forest edge \\
\hline S 3 & $44^{\circ} 33.216^{\prime} \mathrm{N}$ & $17^{\circ} 24.100^{\prime} \mathrm{E}$ & 372 & rheocrene & forest edge \\
\hline S 4 & $44^{\circ} 33.214^{\prime} \mathrm{N}$ & $17^{\circ} 24.092^{\prime} \mathrm{E}$ & 371 & rheocrene & forest edge \\
\hline S 5 & $44^{\circ} 33.156^{\prime} \mathrm{N}$ & $17^{\circ} 23.872^{\prime} \mathrm{E}$ & 403 & rheocrene & forest \\
\hline S 6 & $44^{\circ} 33.162^{\prime} \mathrm{N}$ & $17^{\circ} 23.870^{\prime} \mathrm{E}$ & 405 & captured & forest edge \\
\hline S 7 & $44^{\circ} 33.171^{\prime} \mathrm{N}$ & $17^{\circ} 23.853^{\prime} \mathrm{E}$ & 408 & rheocrene & forest edge \\
\hline S 9 & $44^{\circ} 32.932^{\prime} \mathrm{N}$ & $17^{\circ} 23.562^{\prime} \mathrm{E}$ & 393 & rheocrene & forest \\
\hline S 10 & $44^{\circ} 32.797^{\prime} \mathrm{N}$ & $17^{\circ} 23.386^{\prime} \mathrm{E}$ & 421 & rheocrene & forest \\
\hline S 11 & $44^{\circ} 32.792^{\prime} \mathrm{N}$ & $17^{\circ} 23.378^{\prime} \mathrm{E}$ & 430 & rheocrene & forest \\
\hline S 13 & $44^{\circ} 32.659^{\prime} \mathrm{N}$ & $17^{\circ} 23.240^{\prime} \mathrm{E}$ & 444 & rheocrene & forest \\
\hline S 15 & $44^{\circ} 32.548^{\prime} \mathrm{N}$ & $17^{\circ} 23.292^{\prime} \mathrm{E}$ & 487 & rheopsamocrene & forest \\
\hline S 17 & $44^{\circ} 32.556^{\prime} \mathrm{N}$ & $17^{\circ} 23.298^{\prime} \mathrm{E}$ & 438 & rheocrene & forest \\
\hline S 20 & $44^{\circ} 32.254^{\prime} \mathrm{N}$ & $17^{\circ} 23.117^{\prime} \mathrm{E}$ & 455 & rheocrene & forest \\
\hline S 23 & $44^{\circ} 32.149^{\prime} \mathrm{N}$ & $17^{\circ} 23.150^{\prime} \mathrm{E}$ & 492 & rheocrene & forest \\
\hline S 25 & $44^{\circ} 32.018^{\prime} \mathrm{N}$ & $17^{\circ} 23.015^{\prime} \mathrm{E}$ & 588 & rheocrene & forest \\
\hline S 27 & $44^{\circ} 34.235^{\prime} \mathrm{N}$ & $17^{\circ} 25.738^{\prime} \mathrm{E}$ & 340 & captured & forest edge \\
\hline S 31 & $44^{\circ} 33.135^{\prime} \mathrm{N}$ & $17^{\circ} 24.160^{\prime} \mathrm{E}$ & 431 & rheopsamocrene & forest \\
\hline S 32 & $44^{\circ} 33.131^{\prime} \mathrm{N}$ & $17^{\circ} 24.000^{\prime} \mathrm{E}$ & 382 & captured & forest \\
\hline S 36 & $44^{\circ} 31.422^{\prime} \mathrm{N}$ & $17^{\circ} 21.405^{\prime} \mathrm{E}$ & 666 & rheocrene & forest \\
\hline S 38 & $44^{\circ} 31.567^{\prime} \mathrm{N}$ & $17^{\circ} 20.993^{\prime} \mathrm{E}$ & 720 & captured & forest \\
\hline S 39 & $44^{\circ} 31.660^{\prime} \mathrm{N}$ & $17^{\circ} 20.635^{\prime} \mathrm{E}$ & 707 & captured & village \\
\hline$S 40$ & $44^{\circ} 32.870^{\prime} \mathrm{N}$ & $17^{\circ} 22.721^{\prime} \mathrm{E}$ & 745 & captured & village \\
\hline S 41 & $44^{\circ} 32.621^{\prime} \mathrm{N}$ & $17^{\circ} 22.765^{\prime} \mathrm{E}$ & 681 & captured & village \\
\hline S 43 & $44^{\circ} 31.648^{\prime} \mathrm{N}$ & $17^{\circ} 21.955^{\prime} \mathrm{E}$ & 604 & rheocrene & forest \\
\hline S 44 & $44^{\circ} 31.498^{\prime} \mathrm{N}$ & $17^{\circ} 21.848^{\prime} \mathrm{E}$ & 627 & rheocrene & forest \\
\hline S 46 & $44^{\circ} 30.633^{\prime} \mathrm{N}$ & $17^{\circ} 18.718^{\prime} \mathrm{E}$ & 802 & rheocrene & forest \\
\hline$S 48$ & $44^{\circ} 30.625^{\prime} \mathrm{N}$ & $17^{\circ} 18.789^{\prime} \mathrm{E}$ & 780 & captured & forest \\
\hline
\end{tabular}

Appendix 2: Date of sampling at PSS (S 2-S 48) in September and October 2012 and 2013.

\begin{tabular}{|l|c|l|c|}
\hline Spring code & Date of sampling & Spring code & Date of sampling \\
\hline S 2 & 11.09 .2012$. & S 23 & 19.09 .2012$. \\
S 3 & 11.09 .2012$. & S 25 & 19.09 .2012$. \\
S 4 & 11.09 .2012$. & S 27 & 23.09 .2012$. \\
S 5 & 11.09 .2012$. & S 32 & 23.09 .2012$. \\
S 6 & 11.09 .2012$. & S 36 & 26.09 .2012$. \\
S 7 & 11.09 .2012$. & S 38 & 26.09 .2012$. \\
S 9 & 12.09 .2012$. & S 39 & 06.10 .2012$. \\
S 10 & 12.09 .2012$. & S 40 & 06.10 .2012$. \\
S 11 & 12.09 .2012$. & S 41 & 06.10 .2012$. \\
S 13 & 12.09 .2012$. & S 43 & 06.10 .2012$. \\
S 15 & 17.09 .2012$. & S 44 & 06.10 .2012$. \\
S 17 & 17.09 .2012$. & S 46 & 20.09 .2013$. \\
S 20 & 19.09 .2012$. & S 48 & 20.09 .2013$. \\
\hline
\end{tabular}


M. Płóciennik et al.: Knowl. Manag. Aquat. Ecosyst. (2016) 417, 11

Appendix 3: Date of sampling at three springs (S 3, S 6 and S 31) (EHSS) by spring parts (eucrenal and hypocrenal) and four seasons during 2013.

\begin{tabular}{|c|c|c|c|}
\hline Spring code & Date of sampling & Spring part & Spring part code \\
\hline \multirow{4}{*}{ S 3 } & 10.03 .2013$. & $\begin{array}{c}\text { eucrenal } \\
\text { hypocrenal }\end{array}$ & $\begin{array}{c}\text { e3103 } \\
\mathrm{h} 3103\end{array}$ \\
\cline { 2 - 4 } & 10.06 .2013$. & $\begin{array}{c}\text { eucrenal } \\
\text { hypocrenal }\end{array}$ & $\begin{array}{c}\mathrm{e} 3106 \\
\mathrm{~h} 3106\end{array}$ \\
\cline { 2 - 4 } & 14.08 .2013$. & $\begin{array}{c}\text { eucrenal } \\
\text { hypocrenal }\end{array}$ & $\begin{array}{c}\mathrm{e} 3148 \\
\mathrm{~h} 3148\end{array}$ \\
\cline { 2 - 4 } & 24.09 .2013$. & $\begin{array}{c}\text { eucrenal } \\
\text { hypocrenal }\end{array}$ & $\begin{array}{c}\mathrm{e} 3249 \\
\mathrm{~h} 3249\end{array}$ \\
\hline \multirow{4}{*}{ S 6 } & 10.03 .2013$. & $\begin{array}{c}\text { eucrenal } \\
\text { hypocrenal }\end{array}$ & $\begin{array}{c}\mathrm{e} 6103 \\
\mathrm{~h} 6103\end{array}$ \\
\cline { 2 - 4 } & 10.06 .2013$. & $\begin{array}{c}\text { eucrenal } \\
\text { hypocrenal }\end{array}$ & $\begin{array}{c}\mathrm{e} 6106 \\
\mathrm{~h} 6106\end{array}$ \\
\cline { 2 - 4 } & 14.08 .2013$. & $\begin{array}{c}\text { eucrenal } \\
\text { hypocrenal }\end{array}$ & $\begin{array}{c}\mathrm{e} 6148 \\
\mathrm{~h} 6148\end{array}$ \\
\cline { 2 - 5 } & 24.09 .2013$. & $\begin{array}{c}\text { eucrenal } \\
\text { hypocrenal }\end{array}$ & $\begin{array}{c}\mathrm{e} 6249 \\
\mathrm{~h} 6249\end{array}$ \\
\hline \multirow{4}{*}{ S 31 } & 10.03 .2013$. & $\begin{array}{c}\text { eucrenal } \\
\text { hypocrenal }\end{array}$ & $\begin{array}{l}\mathrm{e} 31103 \\
\mathrm{~h} 31103\end{array}$ \\
\cline { 2 - 5 } & 10.06 .2013$. & $\begin{array}{c}\text { eucrenal } \\
\text { hypocrenal }\end{array}$ & $\begin{array}{c}\mathrm{e} 31106 \\
\mathrm{~h} 31106\end{array}$ \\
\cline { 2 - 5 } & 14.08 .2013$. & $\begin{array}{c}\text { eucrenal } \\
\text { hypocrenal }\end{array}$ & $\begin{array}{c}\mathrm{e} 31148 \\
\mathrm{~h} 31148\end{array}$ \\
\cline { 2 - 5 } & 24.09 .2013$. & $\begin{array}{c}\text { eucrenal } \\
\text { hypocrenal }\end{array}$ & $\begin{array}{c}\mathrm{e} 31249 \\
\mathrm{~h} 31249\end{array}$ \\
\cline { 2 - 4 } & & &
\end{tabular}


M. Płóciennik et al.: Knowl. Manag. Aquat. Ecosyst. (2016) 417, 11

\begin{tabular}{|c|c|c|c|c|c|c|c|c|c|c|c|c|c|c|c|c|c|c|c|c|c|c|c|c|c|c|}
\hline Waste materials & 0 & 0 & 0 & 0 & 0 & 0 & 0 & 0 & 0 & 0 & 0 & 0 & 0 & 0 & 0 & 0 & 0 & 0 & 0 & $N$ & 0 & 0 & 0 & 0 & & 0 \\
\hline Algae & 0 & 0 & 0 & 0 & 0 & 0 & 0 & 0 & 0 & 0 & 0 & 0 & 0 & 0 & 0 & $N$ & 0 & 0 & 0 & 一 & $m$ & 一 & 0 & 0 & 0 & 0 \\
\hline Calcareous sinter & 0 & 0 & 0 & 一 & 0 & 0 & 0 & $\nabla$ & $\forall$ & $m$ & 一 & 0 & 0 & $\checkmark$ & $m$ & 0 & 0 & 0 & 0 & 0 & 0 & 0 & - & 0 & 0 & 一 \\
\hline Lime sinter & 0 & 0 & 0 & $N$ & 0 & 0 & 一 & 0 & 0 & $N$ & $N$ & $N$ & 一 & $N$ & $N$ & 0 & - & $N$ & $N$ & 0 & 0 & 0 & $N$ & - & - & $N$ \\
\hline Stones & $m$ & 0 & 一 & $\nabla$ & 0 & $N$ & $m$ & $N$ & 一 & $N$ & $N$ & $\nabla$ & $m$ & $m$ & $m$ & 0 & - & $m$ & $m$ & 0 & 0 & 0 & $m$ & $m$ & $m$ & $\nabla$ \\
\hline Gravel & $N$ & 0 & 一 & $N$ & 0 & $N$ & $N$ & 0 & 一 & 一 & 0 & 一 & $N$ & $N$ & 一 & 一 & 一 & $N$ & 一 & 0 & 0 & 0 & $N$ & $N$ & - & 一 \\
\hline Sand & $N$ & 0 & 0 & - & 0 & 一 & $m$ & 一 & $N$ & 一 & - & 一 & $m$ & $N$ & 一 & 一 & $m$ & $m$ & 一 & 0 & 0 & 0 & $N$ & - & 0 & 一 \\
\hline Clay & 0 & $N$ & $N$ & 0 & 0 & $N$ & 0 & 0 & 0 & 0 & $N$ & 一 & 0 & 0 & 0 & 0 & 0 & 0 & $N$ & 0 & 0 & 0 & 0 & $N$ & $\nabla$ & 一 \\
\hline Macrophytes & 0 & $N$ & 0 & 0 & 0 & 0 & 0 & $\sim$ & 一 & - & 一 & 0 & 0 & $m$ & 0 & 0 & 0 & 0 & $N$ & - & 0 & 0 & 0 & 0 & 0 & 0 \\
\hline Roots & 0 & 一 & 0 & 0 & 0 & $N$ & 0 & 一 & 0 & 0 & 一 & 一 & 0 & 一 & 0 & 0 & 0 & 0 & 一 & 0 & 0 & 0 & 一 & 0 & 0 & 0 \\
\hline Moss & 0 & 一 & 一 & 一 & 0 & 0 & 一 & $\nabla$ & $m$ & $m$ & 一 & $N$ & 0 & $m$ & $m$ & 0 & 一 & 一 & 一 & 一 & 一 & 0 & $N$ & - & - & 一 \\
\hline Dead branches & 一 & 0 & $m$ & $N$ & $\mathrm{~N}$ & 一 & 一 & 一 & 一 & 一 & $\mathrm{N}$ & 一 & 一 & $N$ & 一 & 0 & 一 & 一 & $N$ & 一 & 0 & 0 & $N$ & 0 & - & 一 \\
\hline Leaf litter & 一 & 一 & $m$ & $m$ & $\forall$ & $N$ & $N$ & $N$ & $N$ & $N$ & $\nabla$ & $N$ & $N$ & $m$ & $m$ & $N$ & 一 & $N$ & $N$ & 0 & 一 & $N$ & $m$ & 0 & - & 一 \\
\hline Detritus & 0 & 一 & $N$ & 一 & $m$ & $N$ & 一 & $N$ & $N$ & 一 & $m$ & 一 & 一 & $m$ & 一 & 一 & $N$ & 一 & $N$ & $N$ & $m$ & $N$ & $N$ & 一 & 0 & 0 \\
\hline Anoxic mud & 0 & 一 & 0 & 0 & $m$ & 0 & 0 & 0 & 0 & 一 & 0 & 0 & 0 & 0 & 0 & $\forall$ & $m$ & 0 & 0 & $m$ & 0 & 0 & 0 & 0 & 0 & 0 \\
\hline Discharge & 一 & 一 & 一 & 一 & 一 & $N$ & $m$ & - & 一 & 一 & 一 & $N$ & $m$ & $N$ & $N$ & 一 & 一 & $N$ & 一 & $N$ & $m$ & 一 & $N$ & $m$ & - & $N$ \\
\hline Oxygen conc. (mg/L) & $\underset{\infty}{-}$ & $\stackrel{\vartheta}{\dot{\gamma}}$ & $n$ & $\underset{r}{0}$ & o. & 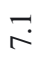 & $\infty$ & o. & $\stackrel{0}{\circ}$ & $\stackrel{+}{\sim}$ & $\underset{0}{\infty}$ & $\underset{\sigma}{0}$ & $\stackrel{r}{r}$ & n? & ب) & $\underset{+}{\stackrel{0}{*}}$ & $\dot{\sigma}^{\infty}$ & $\vec{n}$ & $\vec{r}$ & $\stackrel{+}{\sim}$ & $\stackrel{0}{r}$ & ب) & $\underset{0}{\infty}$ & $\stackrel{n}{+}$ & $\underset{6}{0}$ & $\vec{i}$ \\
\hline Conductivity (cF) & $\forall$ & $n$ & $\checkmark$ & 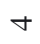 & $n$ & $\checkmark$ & $m$ & $m$ & $\checkmark$ & $m$ & $m$ & $m$ & $\nabla$ & $\checkmark$ & $m$ & $n$ & $\nabla$ & $\nabla$ & $\nabla$ & $n$ & $m$ & 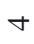 & $\checkmark$ & $m$ & $\checkmark$ & $\forall$ \\
\hline pH value & & $\stackrel{n}{n}$ & N & $\stackrel{9}{r}$ & 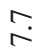 & $\stackrel{r}{r}$ & $\stackrel{0}{r}$ & $\underset{\infty}{\infty}$ & $\vec{\infty}$ & $\vec{\infty}$ & $\hat{N}$ & $\underset{\infty}{\infty}$ & $\underset{\infty}{\infty}$ & $\underset{\infty}{\infty}$ & $\vec{\infty}$ & r & $\stackrel{\infty}{\sim}$ & n? & テ & $\tilde{r}$ & 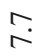 & $\underset{\infty}{0}$ & $\vec{\infty}$ & $\stackrel{\infty}{\sim}$ & $\stackrel{\infty}{\sim}$ & 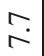 \\
\hline Air temperature $\left({ }^{\circ} \mathrm{C}\right)$ & I & $\stackrel{m}{\sim}$ & $\stackrel{m}{\sim}$ & $\stackrel{\sim}{\sim}$ & $\stackrel{\sim}{\sim}$ & $\stackrel{\sim}{2}$ & $\stackrel{m}{\sim}$ & $\widehat{N}$ & $\widehat{N}$ & ? & $\beth$ & $\infty$ & $\stackrel{n}{n}$ & 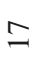 & 이 & $\underline{-}$ & $\vec{\sim}$ & ก̊ & $\stackrel{n}{n}$ & $n$ & $\stackrel{\infty}{-}$ & N & $\ddot{n}$ & ণ & 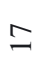 & 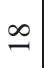 \\
\hline Water temperature $\left({ }^{\circ} \mathrm{C}\right)$ & $\ddot{\sigma}$ & $\stackrel{N}{0}$ & $\stackrel{\infty}{=}$ & $\stackrel{n}{n}$ & $\underline{0}$ & $\underset{\Xi}{ \pm}$ & $\ddot{0}$ & $\begin{array}{l}0 \\
0\end{array}$ & 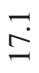 & $\stackrel{\infty}{\infty}$ & $\hat{\sigma}$ & $\begin{array}{l}\stackrel{0}{c} \\
\stackrel{1}{~}\end{array}$ & $\stackrel{\overbrace{}}{\sim}$ & $\stackrel{0}{=}$ & $\begin{array}{l}0 \\
\text { I }\end{array}$ & $\begin{array}{l}0 \\
\stackrel{1}{2}\end{array}$ & $\stackrel{\vartheta}{g}$ & $\stackrel{n}{0}$ & $\stackrel{\infty}{\sim}$ & $\stackrel{\nabla}{\dot{\sim}}$ & $\Xi$ & $\stackrel{9}{r}$ & $\stackrel{0}{0}$ & na & $\stackrel{0}{=}$ & $\stackrel{\infty}{\sigma}$ \\
\hline Snring code & N & $m$ & $\nabla$ & in & 6 & r & $a$ & 음 & $\Xi$ & $\stackrel{m}{7}$ & 10 & 든 & 고 & $\overparen{\sim}$ & 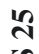 & $\widehat{N}$ & กั & ले & $\infty$ & ले & 워 & 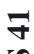 & $\ddot{F}$ & $\mathbb{Z}$ & to & $\underset{+}{\infty}$ \\
\hline Spring code & os & $\omega$ & $\omega$ & $\omega$ & 目 & $\omega$ & 急 & $\omega$ & $\boldsymbol{\Omega}$ & $\omega$ & $\omega$ & 急 & 几 & 几 & $\boldsymbol{s}$ & $\boldsymbol{\omega}$ & $\boldsymbol{\Omega}$ & $\boldsymbol{\omega}$ & $\boldsymbol{\omega}$ & $\omega$ & 冓 & 呈 & 急 & U & Us & $\boldsymbol{\Omega}$ \\
\hline
\end{tabular}


M. Płóciennik et al.: Knowl. Manag. Aquat. Ecosyst. (2016) 417, 11

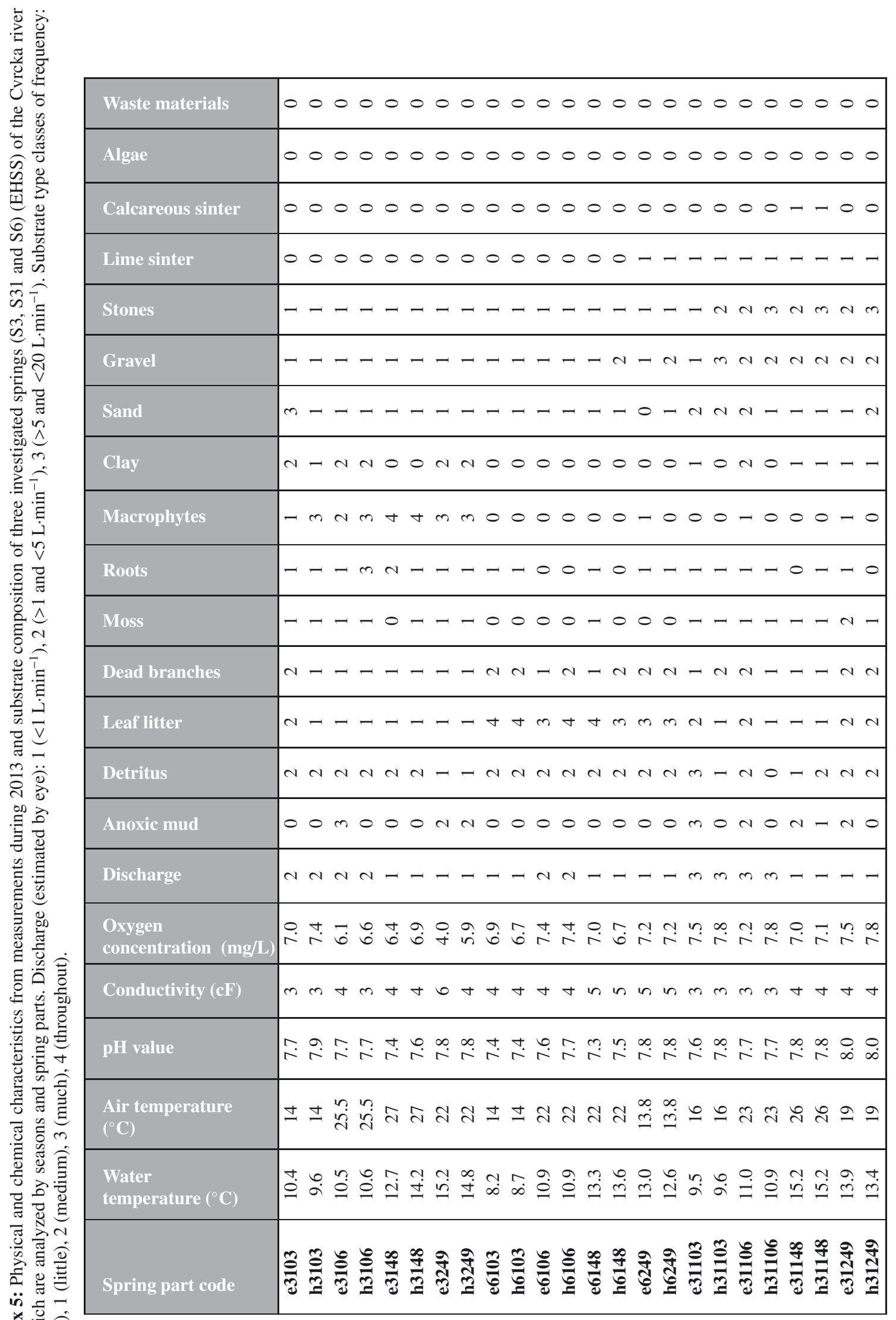


M. Płóciennik et al.: Knowl. Manag. Aquat. Ecosyst. (2016) 417, 11

Appendix 6:

Main parameters of CCA for the PSS.

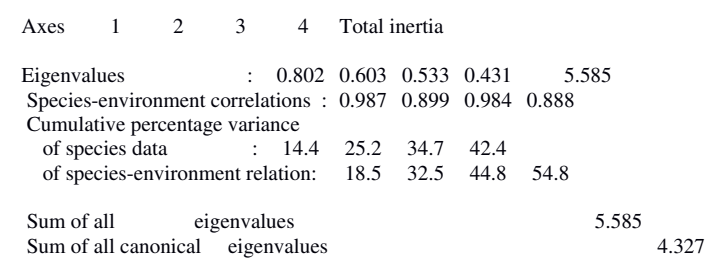


M. Płóciennik et al.: Knowl. Manag. Aquat. Ecosyst. (2016) 417, 11

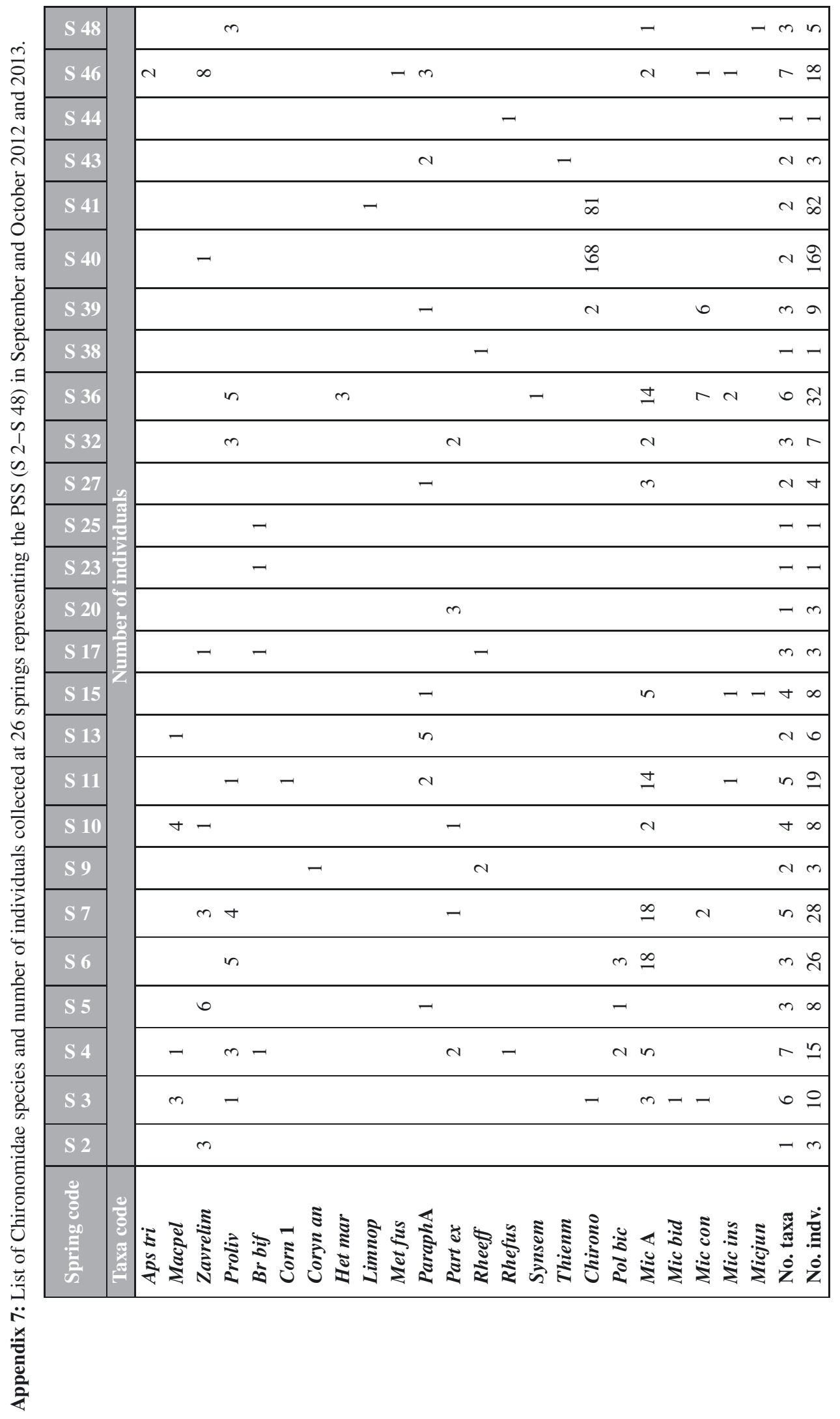


M. Płóciennik et al.: Knowl. Manag. Aquat. Ecosyst. (2016) 417, 11

Appendix 8: List of Chironomidae species and number of individuals collected at three springs (S 3, S 6 and S 31) representing EHSS by spring parts (eucrenal and hypocrenal) at four seasons during 2013.

\begin{tabular}{|c|c|c|c|c|c|c|c|c|c|c|c|c|c|c|c|c|}
\hline Spring code & \multicolumn{6}{|c|}{ S 3} & \multicolumn{7}{|c|}{ S 6} & \multicolumn{3}{|c|}{ S 31} \\
\hline Spring part code & $\frac{\mathbb{\infty}}{\ddot{\infty}}$ & ᄅ্ & $\frac{\&}{2}$ & $\begin{array}{l}\text { ઢ } \\
\stackrel{\Xi}{\sigma}\end{array}$ & $\frac{\mathbb{E}}{\infty}$ & $\frac{\mathbb{E}}{\mathrm{N}}$ & $\frac{8}{8}$ & $\overrightarrow{\vec{\theta}}$ & $\frac{8}{2}$ & $\frac{8}{\infty}$ & $\frac{\vec{\theta}}{\infty}$ & $\begin{array}{l}8 \\
\text { है }\end{array}$ & $\begin{array}{l}\frac{5}{5} \\
6\end{array}$ & $\underset{\mathscr{E}}{\mathscr{E}}$ & 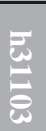 & 党 \\
\hline Taxa code & \multicolumn{16}{|c|}{ Number of individuals } \\
\hline Aps tri & & & 4 & & & 2 & & & & & 1 & 1 & & & & \\
\hline Macpel & & & & 1 & 2 & & & & & & & & & & & \\
\hline Zavrelim & & & & & & & & & 1 & & & & & & & \\
\hline Proliv & & & 1 & & 5 & 1 & 5 & & & 4 & 9 & 9 & 2 & & & \\
\hline Br bif & & & & & & & & & & & & & & & & 1 \\
\hline Prm sty & 1 & & & & & & & & & & & & & & & \\
\hline ParaphA & & 1 & & & & & & 1 & & & & & & 3 & 6 & \\
\hline Partriss & & & & & & 2 & & & & & & & & & & \\
\hline Rheeff & & & & 1 & & 1 & & 2 & & & & & & & & \\
\hline Mic A & 3 & & & & & & 7 & & & 7 & 4 & 10 & 4 & & & \\
\hline Mic bid & 1 & & & & & & 1 & & 1 & & & & & & & \\
\hline Mic con & 5 & & & & & & 1 & & 3 & 1 & 2 & & & & & \\
\hline Mic ins & & & & 1 & & 1 & & & & & & & & & & \\
\hline Chirono & 19 & & 1 & & & & & & & & & & & & & \\
\hline Tan nem & & & & 1 & & & & & & & & & & & & \\
\hline Number of taxa & 5 & 1 & 3 & 4 & 2 & 5 & 4 & 2 & 3 & 3 & 4 & 3 & 2 & 1 & 1 & 1 \\
\hline Number of individuals & 29 & 1 & 6 & 4 & 7 & 7 & 14 & 3 & 5 & 12 & 16 & 20 & 6 & 3 & 6 & 1 \\
\hline
\end{tabular}

